\title{
CryoSat-2 radar altimetry for monitoring freshwater resources of China
}

\author{
Jiang, Liguang; Nielsen, Karina; Andersen, Ole Baltazar; Bauer-Gottwein, Peter
}

\section{Published in:}

Remote Sensing of Environment

Link to article, DOI:

10.1016/j.rse.2017.08.015

Publication date:

2017

Document Version

Peer reviewed version

Link back to DTU Orbit

Citation (APA):

Jiang, L., Nielsen, K., Andersen, O. B., \& Bauer-Gottwein, P. (2017). CryoSat-2 radar altimetry for monitoring freshwater resources of China. Remote Sensing of Environment, 200, 125-139.

https://doi.org/10.1016/j.rse.2017.08.015

\section{General rights}

Copyright and moral rights for the publications made accessible in the public portal are retained by the authors and/or other copyright owners and it is a condition of accessing publications that users recognise and abide by the legal requirements associated with these rights.

- Users may download and print one copy of any publication from the public portal for the purpose of private study or research.

- You may not further distribute the material or use it for any profit-making activity or commercial gain

- You may freely distribute the URL identifying the publication in the public portal

If you believe that this document breaches copyright please contact us providing details, and we will remove access to the work immediately and investigate your claim. 


\title{
CryoSat-2 radar altimetry for monitoring freshwater resources of China
}

\author{
Liguang Jiang $^{\mathrm{a}, *}$, Karina Nielsen ${ }^{\mathrm{b}}$, Ole Baltazar Andersen ${ }^{\mathrm{b}}$, Peter Bauer-Gottwein ${ }^{\mathrm{a}}$ \\ a Department of Environmental Engineering, Technical University of Denmark, Bygningstorvet 115, \\ 2800 Kgs. Lyngby, Denmark \\ b National Space Institute, Technical University of Denmark, Elektrovej 327, 2800 Kgs. Lyngby, \\ Denmark
}

*Corresponding author.E-mail address: ljia@env.dtu.dk

\section{Abstract}

2 Surface water bodies (lakes, reservoirs, and rivers) are key components of the water cycle and

3 are important water resources. Water level and storage vary greatly under the impacts of climate

4 change and human activities. Due to sparse in-situ monitoring networks, a comprehensive national-

5 scale monitoring dataset of surface water bodies in China is not available. Over the last two decades,

6 satellite altimetry has been used successfully for inland water monitoring. Here, we use CryoSat-2

7 radar altimetry to monitor water level variations of large lakes, reservoirs and rivers across China

8 and demonstrate its potential to complement available in-situ monitoring datasets for the country.

9 In this study, over 1000 lakes and reservoirs, and 6 large rivers are investigated. The results

10 show that surface water varied greatly over the past 6 years, e.g. in the Tibetan Plateau, the Junggar

11 Basin, the Northeast China Plain, and the central Yangtze River basin. Estimated changes in volume

12 indicate that surface water variation contributes significantly to terrestrial storage variation,

13 especially in the Qaidam Basin and the Tibetan Plateau. CryoSat-2 is capable of measuring

14 regional-scale river level at high spatial resolution and competitive accuracy as demonstrated by

15 comparison with available in-situ gauging data. The results are encouraging with RMSE values

16 ranging from 0.24 to $0.35 \mathrm{~m}$ for the Heilongjiang-Amur River, 0.22 to $0.6 \mathrm{~m}$ for the Yellow River

17 and 0.22 to $0.5 \mathrm{~m}$ for the Songhua River. Comparatively, accuracy is much lower over the Yangtze 
18 and Pearl Rivers (RMSE $~ 2.6 \mathrm{~m}$ and $~ 3.3 \mathrm{~m}$ ), probably due to intensive inland waterway

19 navigation. CryoSat-2 shows great potential for monitoring surface water at national scale in China.

20 Keywords: CryoSat-2; Radar altimetry; Inland water; Water level; Storage variation; River height

21 1. Introduction

Remotely sensed water level, e.g. from radar altimetry or unmanned aerial vehicle (UAV), is

23 increasingly used for surface water resource monitoring (Berry et al., 2005; Birkinshaw et al., 2010;

24 Crétaux et al., 2016). The benefit of remotely sensed observations is that they are free and easy to

25 access, and have a universal coverage (Jiang et al., 2017b). Therefore, we are able to monitor

26 surface water at large scale for regions poorly gauged or not easy to reach and further advance

27 water resource management and flood forecasting.

28 Because of the impacts of climate change and anthropogenic activities, water resource issues

29 in China are more challenging and have received much attention (Jiang, 2009; Liu and Yang, 2012;

30 Piao et al., 2010). Water storage, both surface- and subsurface water storage, have changed

31 significantly in recent decades (Qiu, 2010). Construction of dams and reservoirs, groundwater

32 exploitation, water diversion projects, land use change, etc., all altered the distribution of surface

33 water storage and groundwater storage. The most dramatic example is that of groundwater over-

34 exploitation in the North China Plain, which is considered the primary reason for groundwater

35 depletion (Shi et al., 2011). Besides, lakes have been undergoing rapid change during the past

36 decades (Ma et al., 2010). China's two largest freshwater lakes, Poyang and Dongting for example,

37 are significantly altered in terms of the hydrological regime, and aquatic ecology by excessive

38 human activities (e.g. artificial channel diversion, landscape modification, dam construction, etc.)

39 (Lai et al., 2013; Yuan et al., 2015). Meanwhile, climate change also greatly affects distribution of

40 water storage. For example, the Yangtze River shows a slight increase in annual runoff since 1960

41 while the Yellow River shows a persistent decline (Piao et al., 2010). Terrestrial water storage

42 (TWS) plays a critical role in local and regional ecological systems and socio-economic 
43 development. However, annual water shortages exceed $50 \mathrm{~km}^{3}$ across the country (Global Water

44 Partnership, 2015). Therefore, monitoring the variations in TWS is important for water resources

45 management and sustainable development.

46 Inland water bodies can be important components of TWS in certain regions of the globe and

47 play a primary role in the global water cycle (Papa et al., 2010). Surface water stored in e.g.

48 reservoirs, lakes, and rivers, has important influence on local climate, ecosystems, and human

49 society. Many rivers, lakes, and reservoirs serve as important drinking water sources. Lake Taihu

50 and Miyun Reservoirs, for instance, are the main drinking water sources for local people in Wuxi

51 and Beijing, respectively, while rivers, like the Yangtze, Yellow, and Pearl serve hundreds of

52 millions of people. Moreover, reservoirs have an important role in water supply and flood control

53 and may become more critical with the increasing frequency and intensity of extreme weather

54 events (Wang et al., 2016). In China, according to the Bulletin of the First National Census for

55 Water (Ministry of Water Resources, 2013), there are 2865 lakes with a surface area greater than 1

$56 \mathrm{~km}^{2}$ and the total lake surface area is about $78000 \mathrm{~km}^{2}$. Additionally, the number of reservoirs was

5798002 with a total storage capacity of $932.3 \mathrm{~km}^{3}$ by 2011. However, the spatio-temporal distribution

58 of surface water variation is very poorly known due to sparse in-situ monitoring networks and

59 restricted access to monitoring datasets.

60 Traditionally, water storage measurements for lakes and reservoirs have relied on in-situ data,

61 i.e. bathymetry and water level. However, in-situ observation at regional-continental scale is often

62 time-consuming and expensive, especially in remote areas. Moreover, for China, existing

63 monitoring datasets for most reservoirs and lakes are not publicly available. In this context, remote

64 sensing technology makes it feasible to measure inland water bodies at regional scale. Satellite

65 altimetry, as an alternative method for surface water level monitoring, has been widely used on

66 inland water bodies (Berry et al., 2005; Birkett, 1995; Crétaux et al., 2016; Schwatke et al., 2015). 
Satellite altimeters obtain surface heights by measuring the two-way travel time of an 68 electromagnetic pulse between the altimeter and the surface. Conventional radar altimeters have 69 been operated for more than three decades. Among the previous and current altimetry missions, 70 CryoSat-2 has advantages due to its dense ground tracks and Synthetic Aperture Interferometric 71 Radar Altimeter (SIRAL) although the full repeat cycle is 369 days. The dense ground tracks make 72 it possible to monitor smaller water bodies and lead to more frequent overpasses for large water 73 bodies than previously (Nielsen et al., 2015). Meanwhile, the SIRAL instrument uses along-track 74 beam formation to generate strips ( $300 \mathrm{~m}$ ) in SAR/SARIn mode which can be superimposed and 75 averaged to reduce noise (Wingham et al., 2006). For example, Nielsen et al (2015) investigated 76 the performance of CryoSat-2 data over small lakes (9 to $40 \mathrm{~km}^{2}$ ) and they found the RMSE values 77 are only $8 \mathrm{~cm}$ or less, even for a lake of annual amplitude of $20-30 \mathrm{~cm}$. Combined with multispectral 78 satellite imagery, such as Landsat, MODIS, Sentinel-2/3, or SAR imagery (Sentinel-1), the 79 dynamic water storage change can be monitored (Crétaux et al., 2015, 2016; Gao et al., 2012; Jiang 80 et al., 2017a; Muala et al., 2014; Song et al., 2013; Zhang et al., 2014). In addition, satellite 81 altimeters also offer the possibility to monitor river levels, flood evolution, and estimate river 82 discharge, in particular for those areas where in-situ measurements are either unavailable or not 83 accessible (Bercher et al., 2013; Michailovsky et al., 2012; Sulistioadi et al., 2015; Villadsen et al., 84 2014). For example, a recent study calibrated a hydrodynamic river model with CryoSat-2 water 85 level in the Brahmaputra river. This study indicated that high spatial resolution CryoSat-2 data is 86 very helpful in calibrating cross-sections without precise knowledge of river bathymetry (Schneider 87 et al., 2017). A recent review of inland water applications of CryoSat-2 has been published by Jiang 88 et al. (2017b).

89 Recently, several studies have used altimetry-derived surface water storage (SWS) changes to 90 complement the terrestrial water storage variations obtained from GRACE (Forootan et al., 2014; 91 Longuevergne et al., 2013; Moore and Williams, 2014; Ndehedehe et al., 2016). The work of Papa 
92 et al. (2015) in the Ganges-Brahmaputra River basin shows that surface water storage variation

93 contributes about $45 \%$ to GRACE-derived TWS variation. Given that the contribution of SWS to

94 TWS can be considerable, especially on a regional scale in regions with significant reservoir and

95 lake storage (e.g. China, Fig. 1), it is of major importance to study the spatio-temporal variations

96 of SWS. This will enable estimation of different components (e.g. groundwater, soil moisture, and

97 surface water) of TWS and their variations (Papa et al., 2015). Nevertheless, national-scale SWS

98 variation in China is unknown till now. Key questions remain unanswered regarding the spatio-

99 temporal dynamics of SWS in China, and the contribution of SWS to TWS.

100 The primary aim of this study is to demonstrate the value of CryoSat-2 radar altimetry data for 101 monitoring surface water bodies of China. Specific key objectives are: (1) to monitor the surface 102 water level (SWL) variation and estimate surface water storage changes (including lakes and 103 reservoirs); (2) to identify the spatio-temporal dynamics of water levels of large rivers; (3) to 104 evaluate the performance of CryoSat-2; and (4) to analyze relations between SWS and TWS change 105 across time and space in China. 


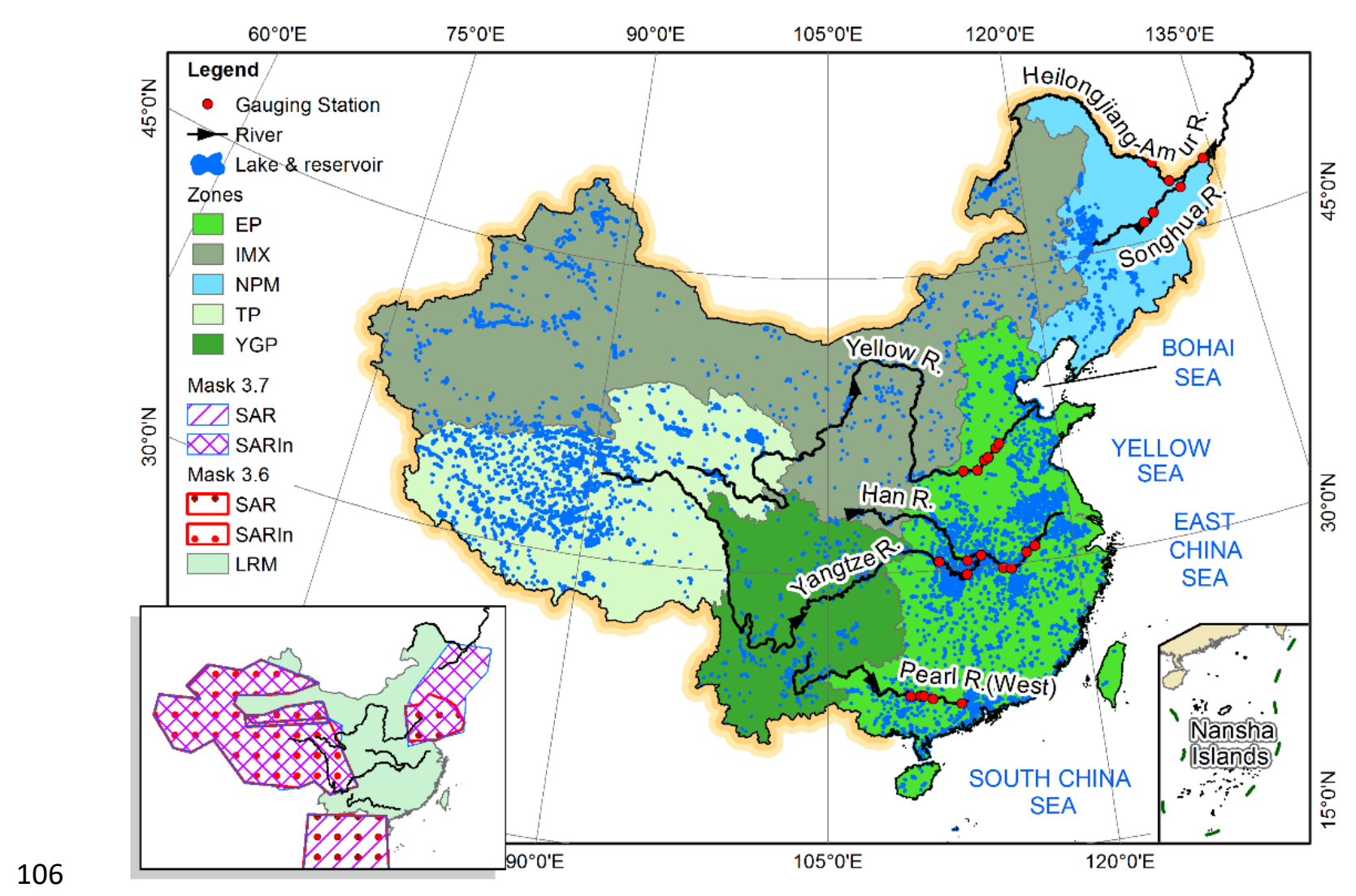

Fig. 1. Map of water bodies in China. Five geographic zones are highlighted; CryoSat-2 geographical masks are also shown in the bottom left corner to present the coverage of different modes.

\section{Materials and methods}

\subsection{Study area and CryoSat-2 mode mask}

China has a large territory with a great diversity of physical and cultural geography. The variation of surface water is affected by both natural and human factors. In this study, we divide

113 lakes and reservoirs into five zones, which consider climate conditions, geography, and 114 administrative boundaries (Ma et al., 2011; Wang and Dou, 1998). The zones are (Fig. 1): (1) the 115 Eastern Plain (EP) $\left(2.07 \times 10^{6} \mathrm{~km}^{2}\right)$, characterized by abundant rainfall and flat topography with 116 developed hydrologic systems; (2) Inner Mongolia and Xinjiang (IMX) $\left(3.7 \times 10^{6} \mathrm{~km}^{2}\right)$, where the

117 climate is arid or semiarid and the drainage system is poorly developed with less permanent runoff;

118 (3) Northeast Plain and Mountain (NPM) $\left(0.81 \times 10^{6} \mathrm{~km}^{2}\right)$, including the Three Northeast Provinces;

119 (4) the general Tibetan Plateau (TP) $\left(1.95 \times 10^{6} \mathrm{~km}^{2}\right)$ including both the Tibet Autonomous Region 
120 and the Qinghai Province, characterized by cold and high altitude environments; and (5) Yunnan-

121 Guizhou Plateau (YGP) $\left(1.14 \times 10^{6} \mathrm{~km}^{2}\right)$.

122 The radar altimeter onboard CryoSat-2 operates in three modes, i.e. low resolution mode 123 (LRM), synthetic aperture mode (SAR), and SAR interferometric mode (SARIn). While the LRM 124 is the same as a conventional pulse-limited radar altimeter, the SAR and SARIn utilize a 125 Delay/Doppler radar altimeter with finer along-track spatial resolution (Keith Raney, 1998). 126 Cryosat-2 is designed to automatically switch to the three modes according to a geographic mode 127 mask, which divides the Earth’s surface into different zones (European Space Agency and Mullar 128 Space Science Laboratory, 2012). China is partially covered by all of the three modes (Fig. 1). The 129 mode mask is subjected to changes from time to time and since 14 December 2015 (mask 3.7), a 130 new SARIn mask was added over the Bohai Sea Rim and the Northeastern China. The coverage of 131 three modes over China is displayed in Fig. 1. For more details about the small changes among 132 different mask versions please refer to ESA CryoSat mission 133 (https://earth.esa.int/web/guest/missions/esa-operational-eo-missions/cryosat/).

\section{$134 \quad$ 2.2. Surface water extent}

135 There are several global surface water datasets available including the MODIS Water Mask 136 (MOD44W) (Carroll et al., 2009), SRTM Water Body Dataset (SWBD, 2003), among others. 137 Considering the resolution and timeliness, we use the dataset from Global Surface Water Explorer 138 (https://global-surface-water.appspot.com/) (Pekel et al., 2016) to derive water body polygons. This 139 water dataset, produced from Landsat imagery, maps the spatial and temporal distribution of water 140 surfaces at the global scale over the past 32 years. Currently all of the mapped datasets are available 141 to download (i.e. occurrence, change, seasonality, recurrence, transitions, and maximum extent). In 142 our study, the water seasonality (2014-2015) dataset is used as input. The values from 1 to 12 stand

143 for the number of months that one pixel is covered by water. In this study, pixels with value 12 are 144 extracted. That means we use permanent water surface mask. 


\subsubsection{Water level time series construction}

The ESA level 1b data product is retracked by an empirical sub-waveform retracker, called

148 Narrow Primary Peak Threshold (NPPT) retracker (Jain et al., 2015). It has proven to provide valid 149 water level and outperform the ESA L2 data (Jain et al., 2015; Nielsen et al., 2015; Villadsen et al., 150 2016). For lakes and reservoirs water level time series are constructed by the following steps:

151 Step 1. Point data are first selected with water masks.

Step 2. The obvious outliers are removed by comparing water level (h) with SRTM elevation (e) (Jarvis et al., 2008), i.e. data points are discarded if $|\mathrm{h}-\mathrm{e}|>20 \mathrm{~m}$.

Step 3. Water bodies with more than 5 crossings are retained.

Step 4. For each water body, the estimation of the along-track mean values and time series are calculated using the "R" package "tsHydro", which is publicly available from Github (https://github.com/cavios/tshydro). This package is based on a state-space model proposed

The data processing for rivers is different from that of lakes and reservoirs due to the river's bendiness (sinuosity) which causes many crossovers per track at different reaches. The main procedures are described below:

164 The first two steps are the same as above.

Step 3. For each crossing track, a simple clustering is applied by checking the distance between two consecutive measurements. If the distance is larger than $1 \mathrm{~km}$ (the along-track distance between two consecutive samples is $~ 300 \mathrm{~m}$ ), we split this track into different parts to make sure that the measurements of each cluster are from the same reach. 
Step 4. For each cluster, a filtering is performed to get the mean value of each track: a measurement is discarded if $|\mathrm{h}-\mu|>3 \sigma(\mu$ is mean value and $\sigma$ is the along-track standard

171 deviation).

Step 5. The measurements (from step 4) are then interpolated to the closest in-situ station for validation purpose based on the local average slope.

\subsubsection{Space-time interpolation}

175 The dense ground tracks allow to map river level variations in both time and space (chainage). 176 However, the initial point data are not easy to visually interpret and identify the spatio-temporal 177 variation of water level. In order to have better visual interpretation, gridded water level data (time 178 by chainage) are generated by interpolation as follows:

179 Step 1: A template grid (7 days by $10 \mathrm{~km})$ is created for each year (2010 -2016).

Step 2: Cubic interpolation at each grid point is performed for each year using water level from step 4 in previous section, and then 7 gridded layers are obtained.

Step 3: For each grid point (6 - 7 values during 2010 - 2016), the median value (avoid the extremely dry/wet year) is used to generate a space-time map.

\subsubsection{Trend and amplitude estimation}

In order to estimate trends for lakes and reservoirs, a weighted linear regression model is used.

186 Due to the seasonality of water level in most lakes and reservoirs, a linear-periodic model is fitted 187 for those having a time series length of more than 15 points. Following Villadsen et al (Villadsen 188 et al., 2015), this model is defined as:

$$
h(t)=a+b t+c \sin (2 \pi t)+d \cos (2 \pi t)
$$

190 where $t$ is the time in decimal years; $a$ and $b$ are the linear coefficients, and $c$ and $d$ are the

191 periodic coefficients, respectively. From this model, the annual amplitude $(H)$ is estimated as:

$$
H=\sqrt{c^{2}+d^{2}}
$$




\subsection{Water storage change}

194

195

196

197

198

199

To assess the water storage changes in lakes and reservoirs, water extent $(A)$ and water level change $(\Delta h)$ are needed. Ideally, dynamic water extent datasets should be used to calculate accurate storage change. Due to the lack of such datasets, we assume that water extent is constant during the investigated period. Thus, water storage change can be obtained by multiplying $A$ with $\Delta h$. The error induced by this assumption is about $2.5 \%$ after investigating 71 lakes in the Tibetan Plateau.

\subsection{GRACE gravimetry}

The Gravity Recovery and Climate Experiment (GRACE) mission measures the variations in gravitational field on a monthly scale, which can provide vertically integrated TWS change. The GRACE data used in this study is the latest version (RL05) L3 from the Center for Space Research (CSR), University of Texas at Austin, German Research Centre for Geosciences (GFZ), and Jet Propulsion Laboratory (JPL), respectively (http://grace.jpl.nasa.gov/). Each solution is processed by removal of atmospheric pressure/mass changes and the degree 2 and order 0 (C20) coefficients are substituted with those from Satellite Laser Ranging (Cheng et al., 2011) and degree 1 coefficients with those from Swenson et al (Swenson et al., 2008). The data are further processed by multiplying by the scale factors at the grid scale to restore much of the energy removed by the de-striping, Gaussian smoothing, and truncation to the land grids (Landerer and Swenson, 2012). As for the accuracy, the GRACE error estimates are based on measurement and leakage errors, and the total error in TWS for a given grid can be calculated as:

$$
\operatorname{Err}=\sqrt{E_{M}^{2}+E_{L}^{2}}
$$

where $E r r$ is the total error, $E_{M}$ and $E_{L}$ are measurement and leakage errors, respectively. Finally, an ensemble mean solution is achieved by averaging the three solutions. 
Daily water level data of rivers are extracted from the Hydrological Yearbook published by

217 the Chinese Ministry of Water Resources (MWR, 2014). The reservoir storage change data are

218 extracted from China Water Resources Bulletin (http://www.mwr.gov.cn/) and SongLiao Water

219 Resources Bulletin (http://www.slwr.gov.cn/). Precipitation data are downloaded from the China

220 Meteorological Data Sharing Service System (http://data.cma.cn/en). Water level of 3 lakes is

221 downloaded from the Third Pole Environment Database (http://www.en.tpedatabase.cn/).

\section{3. Results}

223 In this section, an overview of lakes and reservoirs is presented to show how much spatial 224 detail CryoSat-2 can deliver, followed by detailed analysis of the temporal variations of these water 225 bodies. Next, we show the CryoSat-2 derived water levels for 6 large Chinese river systems. Then, 226 we evaluate the accuracy and precision of CryoSat-2 over inland water.

\section{3.1. Overview of monitored water bodies}

228 In total, 1334 lakes and reservoirs $\left(>5 \mathrm{~km}^{2}\right)$ are visited by CryoSat-2 over China during 2010 229 to 2016, providing basic water level information. After outlier removal, time series of 1163 water 230 bodies are obtained. Table 1 lists the number of water bodies having different number of passes. 231 Considering the estimates of linear trend and annual amplitude, only those having at least 10 passes 232 are considered in this study. Overall, TP and EP are the two zones with the most lakes, accounting 233 for $50 \%$ and $23 \%$ of the total number of water bodies, respectively (Table 2). Meanwhile, lakes in 234 TP comparatively have more passes (avg. 25 passes per lake) due to their large sizes.

Table 1. Number of CryoSat-2 passes over water bodies

\begin{tabular}{ccccccccccccc}
\hline $\begin{array}{c}\text { Number of } \\
\text { passes }\end{array}$ & 5 & 6 & 7 & 8 & 9 & 10 & 11 & 12 & 13 & 14 & 15 & $>15$ \\
\hline $\begin{array}{c}\text { Number of } \\
\text { water bodies }\end{array}$ & 43 & 40 & 49 & 71 & 77 & $\mathbf{9 2}$ & $\mathbf{6 4}$ & $\mathbf{7 3}$ & $\mathbf{5 2}$ & $\mathbf{3 5}$ & $\mathbf{3 7}$ & $\mathbf{5 3 0}$ \\
\hline
\end{tabular}


In zone TP, $56 \%$ of water bodies exhibit an upward trend and the rising rates of rising lakes

237 are far larger than the declining rates of declining lakes. At the national scale, surface water bodies

238 show a dominant increasing trend although some regions have an almost even split between rising

239 and declining lakes (Table 2). Out of the 1334 lakes and reservoirs surveyed by CryoSat-2, 288

240 lakes and reservoirs show a significant changing trend; of those, around 58\% are located in region

241 TP.

Table 2. Statistics of water level and storage changes of water bodies in the five lake zones

\begin{tabular}{ccccc}
\hline Lake zone & Trend & $\begin{array}{c}\text { Number } \\
\text { (percentage) }\end{array}$ & $\begin{array}{c}\text { Mean changing } \\
\text { rate }(\mathrm{m} / \mathrm{yr})\end{array}$ & $\begin{array}{c}\text { Storage change } \\
\text { rate }\left(10^{8} \mathrm{~m}^{3} / \mathrm{yr}\right)\end{array}$ \\
\hline \multirow{2}{*}{ EP } & rising & $142(70 \%)$ & 0.330 & $9.5 \pm 23.6$ \\
& declining & $62(30 \%)$ & -0.448 & $25.9 \pm 24.4$ \\
\multirow{2}{*}{ IMX } & rising & $64(52 \%)$ & 0.302 & $-12.4 \pm 30.1$ \\
& declining & $58(48 \%)$ & -0.219 & \multirow{2}{*}{$35.5 \pm 55.2$} \\
\multirow{2}{*}{ NPM } & rising & $60(65 \%)$ & 0.267 & \\
& declining & $33(35 \%)$ & -0.573 & $5.4 \pm 25.4$ \\
\multirow{2}{*}{ TP } & rising & $247(56 \%)$ & 0.228 & \\
& declining & $194(44 \%)$ & -0.117 & 0.919 \\
\multirow{2}{*}{ YGP } & rising & $14(61 \%)$ & -0.592 & \\
& declining & $9(39 \%)$ &
\end{tabular}

243 Although water level changes vary zonally, several hotspots can be identified from the map of

244 changing rates (Fig. 2a). Specifically, water bodies in Junggar Basin, Huai River Basin, and Jilin

245 Province show a dominant declining trend. In contrast, those in Songnen Plain and North TP, i.e.

246 Qiangtang Reserve, show a marked rising trend. 
(a)

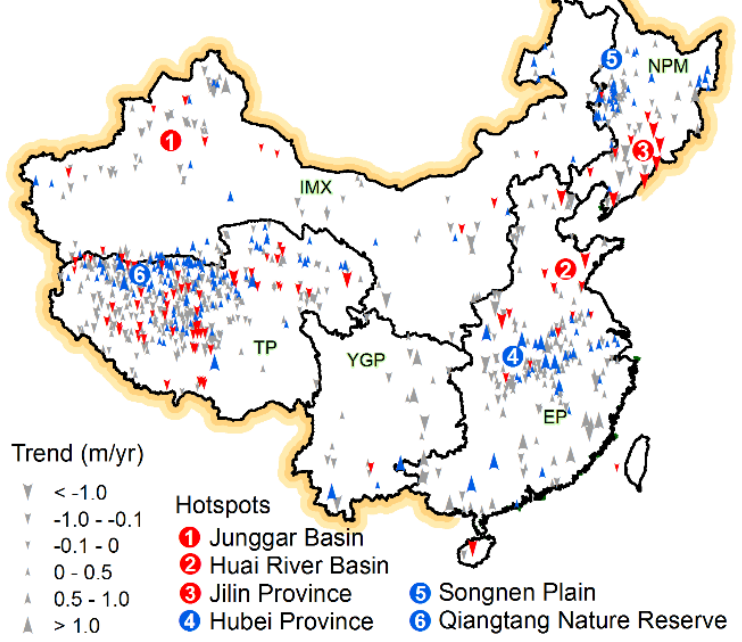

(b)

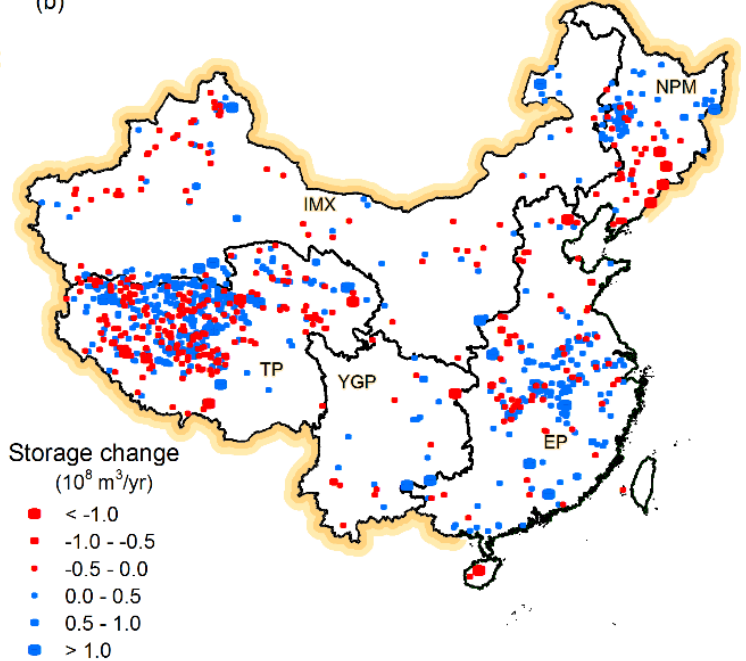

Fig. 2. Distribution of lake/reservoir changing rates (a) (Solid red and blue arrows indicate significant trends at the 5\% level) and storage change (b)

\subsection{Variations of lakes and reservoirs}

\subsubsection{Annual fluctuation of water level}

Overall, annual amplitudes of lakes are relatively smaller than amplitudes of reservoirs. For example, annual amplitudes of lakes in TP are between $0-1.5 \mathrm{~m}$ and the average is $0.52 \pm 0.45 \mathrm{~m}$, while those of reservoirs located in the lower portions of the Yangtze River basin and Northeast Plain are larger than $5 \mathrm{~m}$ (Fig. 3). This is mainly due to human regulation. In fact, reservoirs did not show a very clear annual fluctuation pattern in recent years (Fig. 3).

In many cases, annual fluctuations of larger lakes are lower compared to smaller ones. An example is given in Fig. 3 from region TP. We can see that Zhari NamCo $\left(1072 \mathrm{~km}^{2}\right)$ has a smaller annual fluctuation compared to Aru Co $\left(113 \mathrm{~km}^{2}\right)$ and Gyaring Lake (538 km²). 

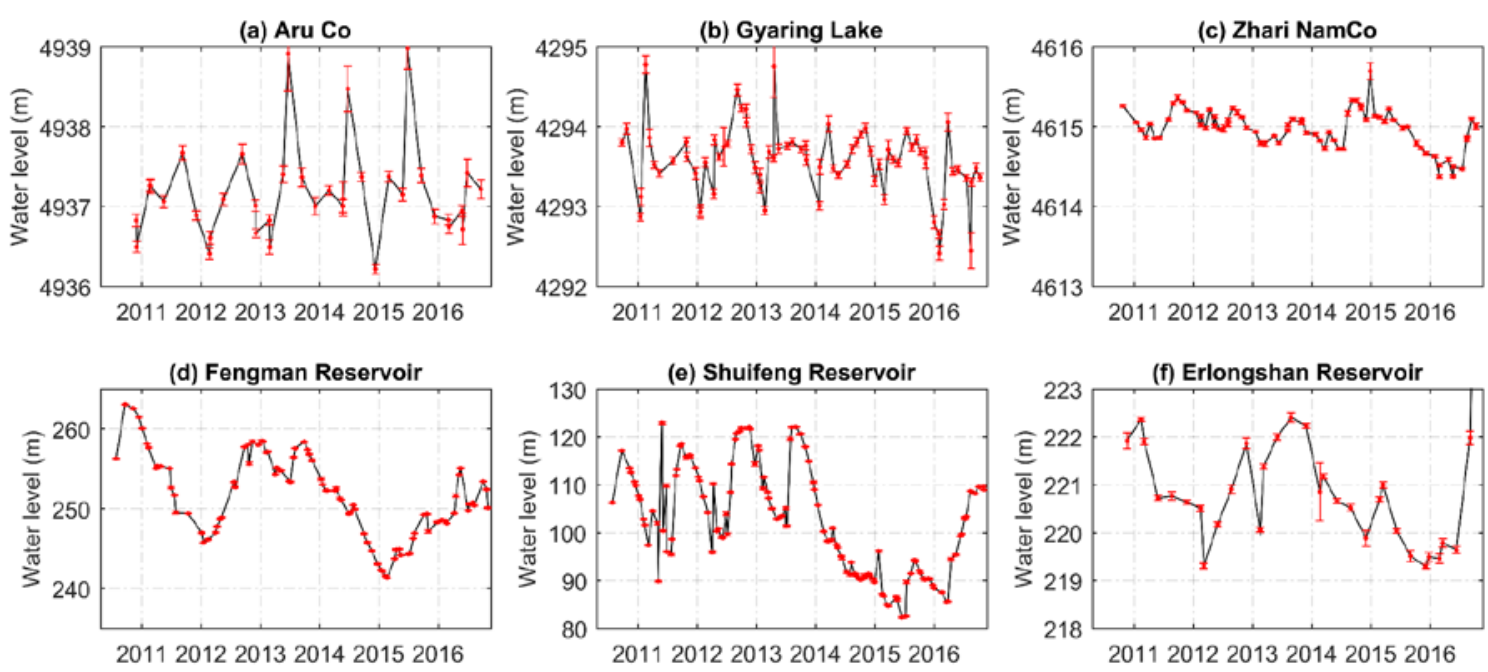

Fig. 3. Level changes of four lakes in TP lake region (a-c) and very large reservoirs (storage capacity $>1$ $\times 10^{9} \mathrm{~m}^{3}$ ) in NPM lake region (d-f)

\subsubsection{Surface water storage changes}

The surface water storage change varies greatly from region to region as shown in Fig. $2 \mathrm{~b}$. Region TP and IMX gained water storage while NPM lost water storage in the period 2010-2016. Specifically, the estimated SWS changes in TP and IMX are 35.5 and $25.9 \times 10^{8} \mathrm{~m}^{3} / \mathrm{yr}$, respectively (Table 2). It is obvious that in the northwest of IMX, i.e. the Junggar Basin and south of NPM, SWS loss was dominant. EP and YGP exhibited slightly increasing SWS trends although some lakes/reservoirs experienced declining trends.

Some lakes show very significant storage changes and play a dominant role in the regional surface water storage variation. For instance, Hulun Lake, Poyang Lake, and many lakes in the Tibetan Plateau have annual average storage increases exceeding $1 \times 10^{8} \mathrm{~m}^{3} / \mathrm{yr}$ (Table D1).

Reservoirs have relatively smaller areas but larger storage capacity than lakes, thus play a dominant role in seasonal SWS. However, at intra-annual scale, large reservoirs did not vary greatly due to human intervention. For instance, Three Gorges reservoir did not show a significant changing trend. 
We investigated 6 large rivers, i.e. the mainstream of the Yangtze River and its tributary - Han

279 River, the Yellow River, the Pearl River (the west part, i.e. West River), and the Heilongjiang280 Amur River and its tributary - Songhua River. The following sections will present the water level 281 variation in detail.

\subsubsection{The Yangtze River}

Figure 4 shows the river level profile of the Yangtze River. Data quality over the upper part is relatively poor due to the narrow valley, canyons, and gorges in the mountainous areas. The lower reach after the Three Gorges Dam is relatively flat, especially downstream of river kilometer 1900

286 (measured from the estuary) (Fig. 4a). The level drops from above $4500 \mathrm{~m}$ to a few hundred meter 287 along the upper course while the lower part is very flat. The fluctuation of water level of the lower 288 reach is about $10 \mathrm{~m}$ and decreases close to the estuary (inset of Fig. 4a), which is confirmed by the 289 available in-situ measurement. The lower flat reach has more CryoSat-2 crossings and the 290 interpolated space-time map generally captures the high flow around day of year 200 (Figs. 4c \& 291 4d). However, the data over some sections are sparse and annual mean level is over-/under292 estimated due to the uneven seasonal data sampling. As shown in Fig. 4c, the heights of several 293 hotspots are presented along the chainage, such as those located around river km 1000. Despite all 294 these limitations, the interpolated water level profile still presents the general annual flow pattern 295 (Fig. 4d). Nevertheless, from these graphs, much hydrological information (e.g. river level profile, 296 water level slope, flow regime) are provided by CryoSat-2. This indicates that CryoSat-2 can 297 potentially facilitate river modeling. 

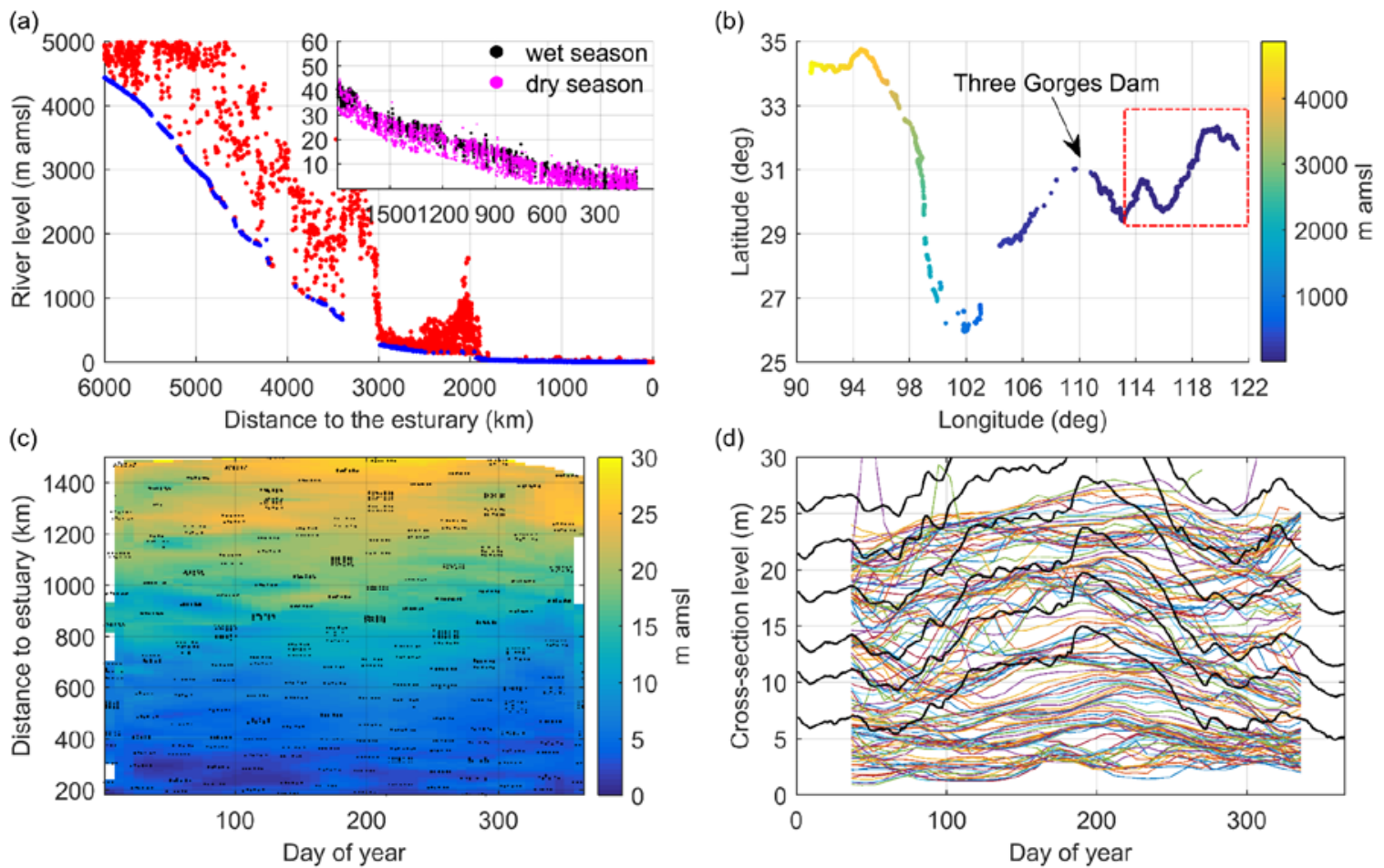

Fig. 4. The Yangtze River height profile: (a) CryoSat-2 data distribution along river course (red points are outliers); (b) map of river profile with colored heights; (c) spatio-temporal distribution of CryoSat-2 river water level (location is indicated by red rectangle in b; black dots indicate retracked water level); and (d) interpolated sectional level against in-situ data (black lines) corresponding to c.

\subsubsection{The Yellow River}

In contrast to the data of the Yangtze River, the data quality and derived river height profile

of the Yellow River are much less noisy, especially in the downstream portion, where the river

306 flows through a flat plain area. (Figs. 5a and 5b). The river slope is quite consistent throughout the

307 last $800 \mathrm{~km}$ and the slope is very gentle at $0.1 \%$ o $(0.1 \mathrm{~m} / \mathrm{km})$ although the local surface slope is varying between 0.05 and $0.15 \mathrm{~m} / \mathrm{km}$. The fluctuation of water level is small ( 1- $2 \mathrm{~m})$ downstream of Xiaolangdi Dam and the flow regime cannot be clearly seen from the space-time interpolation map due to the small inter-annual variation (Fig. 5c). However, for most of the cross sections, the annual variation of water level is reasonable compared to that of the Yangtze River, and the pattern 

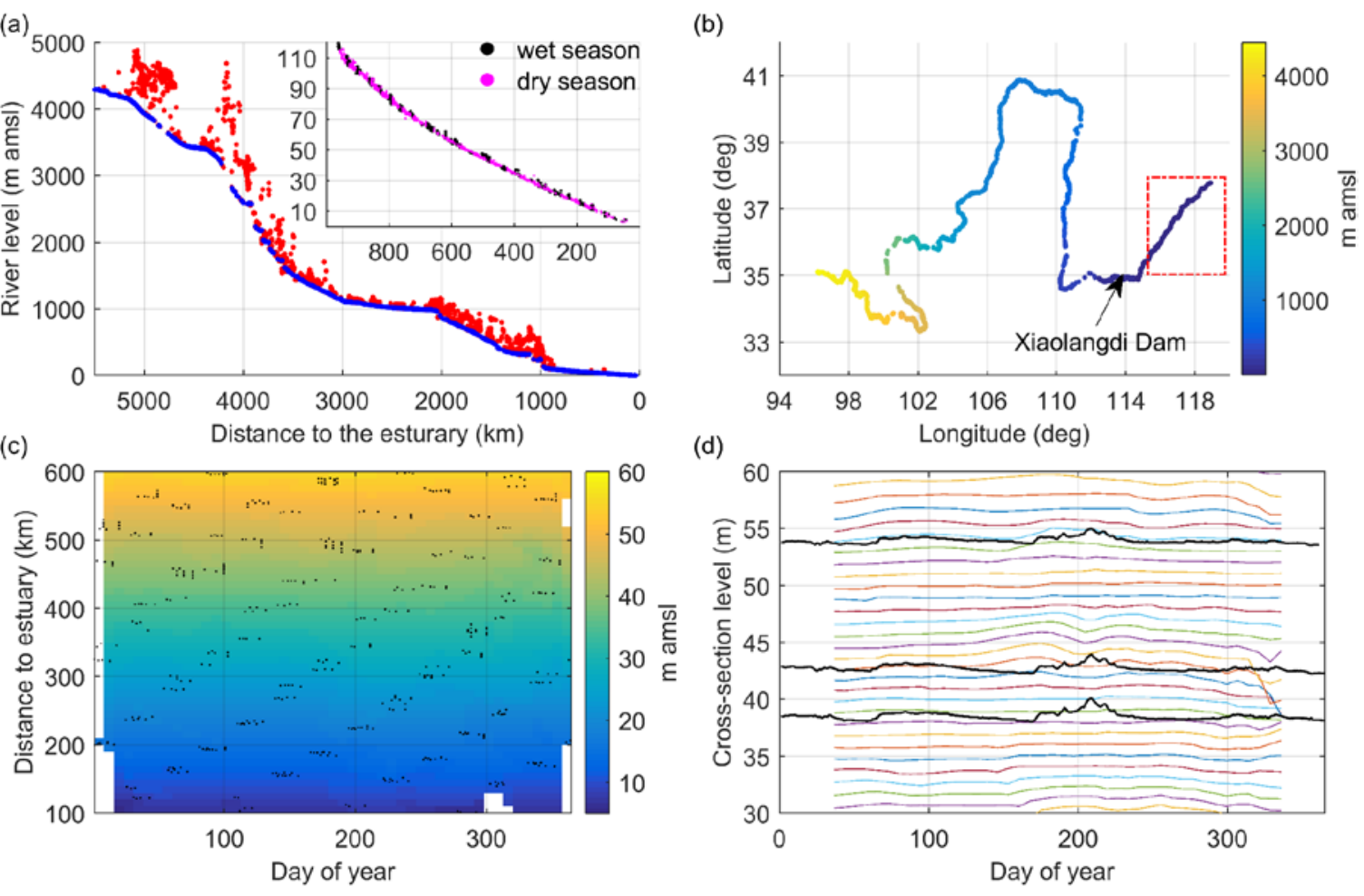

Fig. 5. The same as Fig. 4 but for the Yellow River.

3.3.3. The Heilongjiang-Amur River

Data quality over this region is very good, especially for the Songhua River where many valid

317 measurements are obtained. From the profile of river level versus chainage (Fig. 6d), we can see

318 that the slope of the Songhua River is just about $0.1 \%$ o $(0.1 \mathrm{~m} / \mathrm{km})$, similar to the Yellow River.

319 The river level profiles are very well presented at high spatial resolution (Fig. 6), which is not

320 possible using any of the previous altimetry missions. This is a unique capability of Cryosat-2 due

321 to its dense ground tracks. Fig. 7 shows in detail the water level maps of river reach where in-situ

322 data are available. Generally, the space-time river level maps of Heilongjiang-Amur and its largest

323 tributary, Songhua River, are captured well and are in agreement with in-situ measurements (see

324 details in section 3.4). High and low flow periods are very well observed. These river level graphs

325 reflect the high spatial coverage of CryoSat-2 data and a satisfactory data quality. 

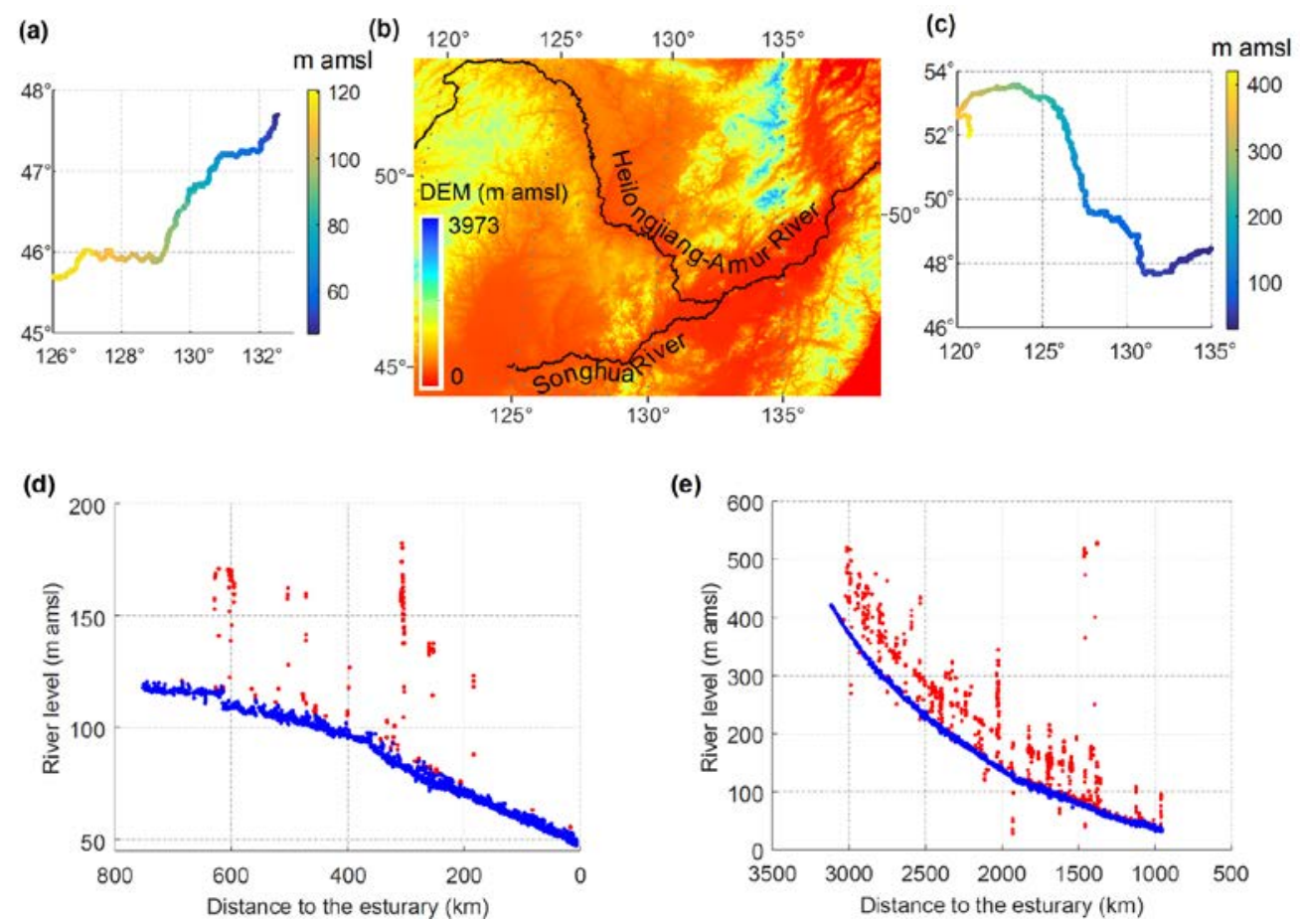

Fig. 6. River level and the longitudinal profile of Songhua River (a and d) and Heilongjiang-Amur River (c and e), and the SRTM DEM (b) in this region. Outliers are in red in d and e.

(a)

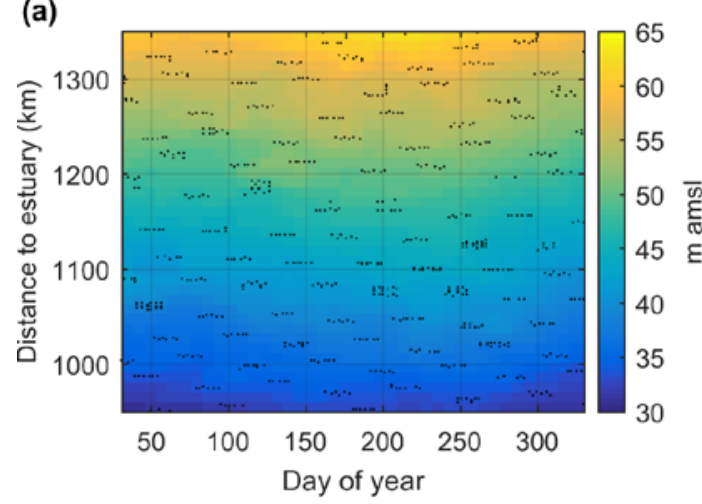

(c)

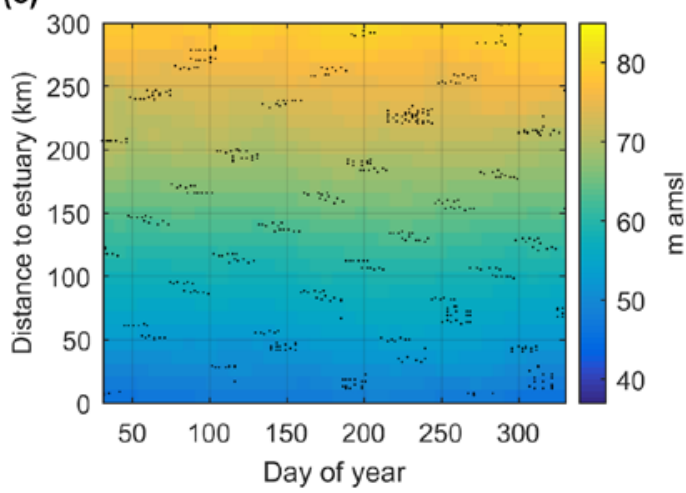

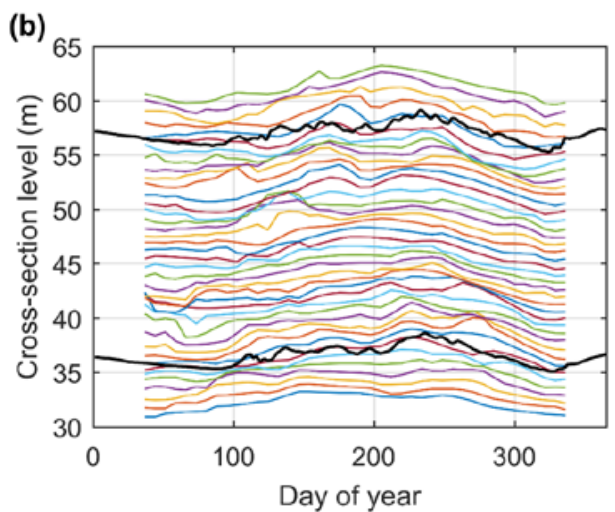

(d)

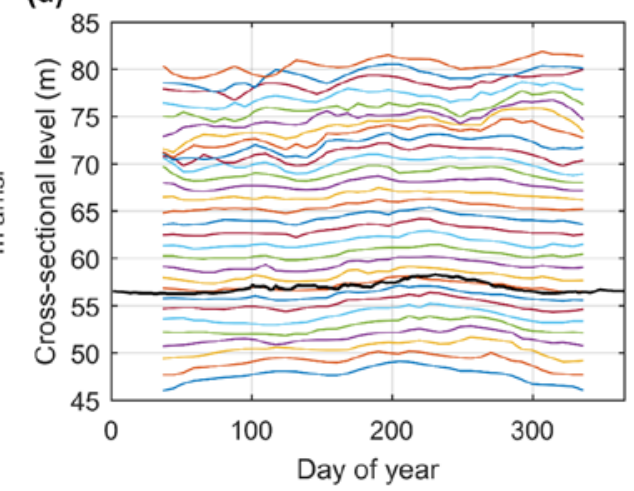

Fig. 7. Water level maps of the Heilongjiang-Amur River (a and b) and its tributary - Songhua River (c and 


\subsection{Evaluation of CryoSat-2 derived water level}

334

343 Heilongjiang-Amur River with respect to the RMSE. This result is also comparable to that of SAR

344 in the Amazon River reported by Villadsen et al. (2016). Moreover, the performance of LRM over

345 these rivers is clearly better than that for the Yangtze River and Pearl River although the last two

346 rivers are much wider than other Chinese rivers. This also explains the poor interpolation result of

347 the Yangtze River in previous section.

Table 3. Validation of virtual stations of CryoSat-2 against in-situ data.

\begin{tabular}{|c|c|c|c|c|c|c|c|}
\hline River & $\begin{array}{l}\text { Station } \\
\text { Name }\end{array}$ & $\begin{array}{c}\text { Position } \\
(\mathrm{km})\end{array}$ & Mode ${ }^{\S}$ & Width (km) & $\begin{array}{c}\text { Number of } \\
\text { measurements }\end{array}$ & RMSE (m) & $\mathrm{R}^{2}$ \\
\hline \multirow{8}{*}{ Yellow River } & Huayuankou & 833 & LRM & $\sim 1.4$ & 8 & 0.25 & 0.95 \\
\hline & Jiahetan3 & 730 & LRM & $\sim 0.9$ & 13 & 0.36 & 0.86 \\
\hline & Gaocun4 & 622 & LRM & $\sim 0.5$ & 10 & 0.60 & 0.43 \\
\hline & Susizhuang2 & 589 & LRM & $\sim 0.5$ & 12 & 0.22 & 0.96 \\
\hline & & & Both & & 13 & 0.36 & 0.88 \\
\hline & Sunkou & 484 & LRM & $\sim 0.3$ & 7 & 0.28 & 0.79 \\
\hline & & & SARIn & & 6 & 0.41 & 0.9 \\
\hline & huangzhuang & 444 & LRM & $\sim 0.2$ & 10 & 0.11 & 0.99 \\
\hline \multirow{4}{*}{ Yangtze River } & Majiadian & 1789 & LRM & $\sim 1.0$ & 15 & 4.02 & 0.21 \\
\hline & Luoshan & 1454 & LRM & $\sim 1.4$ & 7 & 1.90 & 0.7 \\
\hline & Hankou & 1242 & LRM & $\sim 1.2$ & 7 & 1.87 & 0.51 \\
\hline & Matouzhen & 1013 & LRM & $\sim 1.3$ & 13 & 3.78 & 0.02 \\
\hline
\end{tabular}




\begin{tabular}{|c|c|c|c|c|c|c|c|}
\hline & Jiujiang & 952 & LRM & $\sim 2.0$ & 15 & 2.84 & 0.55 \\
\hline & Anqing & 772 & LRM & $\sim 1.2$ & 17 & 2.42 & 0.3 \\
\hline & Datong2 & 685 & LRM & $\sim 1.7$ & 16 & 1.62 & 0.77 \\
\hline Han River & Xiantao2 & 145 & LRM & $\sim 0.3$ & 5 & 0.14 & 0.99 \\
\hline \multirow{5}{*}{$\begin{array}{l}\text { Pearl River } \\
\text { (West R.) }\end{array}$} & Wuxuan2 & 458 & LRM & $\sim 0.3$ & 8 & 0.37 & 0.97 \\
\hline & $\begin{array}{l}\text { Dahuang- } \\
\text { jiangkou2 }\end{array}$ & 362 & LRM & $\sim 0.5$ & 5 & 5.66 & 0.01 \\
\hline & Pingnan & 338 & LRM & $\sim 0.7$ & 12 & 5.95 & $<0.01$ \\
\hline & Tengxian & 265 & LRM & $\sim 0.7$ & 10 & 1.16 & 0.01 \\
\hline & Gaoyao & 42 & LRM & $\sim 1.3$ & 4 & 3.32 & 0.68 \\
\hline \multirow{3}{*}{ Songhua River } & Tonghe & 457 & LRM & $\sim 1.1$ & 13 & 0.50 & 0.31 \\
\hline & Yilan & 354 & LRM & $\sim 0.6$ & 7 & 0.22 & 0.99 \\
\hline & Fujin & 80 & LRM & $\sim 1.7$ & 14 & 0.30 & 0.96 \\
\hline \multirow{3}{*}{$\begin{array}{l}\text { Heilongjiang- } \\
\text { Amur River }\end{array}$} & Jiayin & 1535 & LRM & $\sim 1.0$ & 8 & 0.30 & 0.87 \\
\hline & Luobei & 1309 & LRM & $\sim 1.1$ & 10 & 0.24 & 0.94 \\
\hline & Fuyuan & 1010 & LRM & $\sim 1.7$ & 11 & 0.35 & 0.92 \\
\hline
\end{tabular}

349 § : during the period when in-situ data are available

350 3.4.2. Evaluation of precision

351 To evaluate the water level data quality, we have calculated the standard deviation (SD) of the

352 along-track measurements. The SD gives a measure of how precise the observations are along each

353 track. Over lakes, LRM and SARIn perform almost equally well and the median SD is below 0.1

$354 \mathrm{~m}$ as expected due to the large area of water surface.

355 Because rivers are normally much narrower than lakes, we considered the tracks with two or 356 more measurements. Table 4 shows the along-track SD of water level for the 6 rivers during 357 different seasons. It is obvious that SDs of the Yangtze River and the Pearl River are very large 358 compared to those of other rivers. And the downstream of the Yangtze is strikingly high, especially 359 in the dry season (Table 4). We will discuss the possible reasons in Discussion. Moreover, the 360 SAR/SARIn modes do not outperform LRM significantly (Table 4). 
(Units: $\mathrm{m}$ )

\begin{tabular}{|c|c|c|c|c|c|c|}
\hline & River & $\begin{array}{c}\text { SD of Wet } \\
\text { season }\end{array}$ & $\begin{array}{l}\text { SD of Dry } \\
\text { season }\end{array}$ & SD of All & SD of LRM & $\begin{array}{c}\text { SD of } \\
\text { SAR/SARIn }\end{array}$ \\
\hline \multirow{3}{*}{ Yellow R. } & All & $0.33(0.18)$ & $0.40(0.20)$ & $0.37(0.19)$ & \multirow{3}{*}{$0.34(0.18)$} & $\begin{array}{l}\text { SAR } \\
\text { SA }\end{array}$ \\
\hline & Upstream $^{\#}$ & $0.35(0.20)$ & $0.42(0.21)$ & $0.39(0.21)$ & & $\begin{array}{c}0.20(0.09) \\
\text { SARIn }\end{array}$ \\
\hline & Downstream ${ }^{\#}$ & $0.28(0.14)$ & $0.36(0.17)$ & $0.32(0.16)$ & & $0.49(0.32)$ \\
\hline \multirow{3}{*}{ Yangtze R. } & All & $0.98(0.59)$ & $1.34(0.90)$ & $1.18(0.76)$ & \multirow{3}{*}{$1.33(0.99)$} & \multirow{3}{*}{$0.71(0.51)$} \\
\hline & Upstream* $^{*}$ & $0.63(0.45)$ & $0.77(0.54)$ & $0.71(0.51)$ & & \\
\hline & Downstream* $^{*}$ & $1.04(0.73)$ & $1.61(1.30)$ & $1.33(0.99)$ & & \\
\hline \multicolumn{2}{|l|}{$\overline{\text { Han R. }}$} & $0.38(0.16)$ & $0.47(0.16)$ & $0.42(0.16)$ & $0.42(0.16)$ & NA \\
\hline \multicolumn{2}{|l|}{ Pearl R. } & $0.88(0.25)$ & $0.90(0.22)$ & $0.89(0.23)$ & $0.89(0.23)$ & NA \\
\hline \multicolumn{2}{|l|}{ Songhua R. } & $0.36(0.16)$ & $0.34(0.16)$ & $0.35(0.16)$ & $0.36(0.16)$ & $0.29(0.13)$ \\
\hline \multicolumn{2}{|c|}{ Heilongjiang-Amur R. } & $0.39(0.17)$ & $0.49(0.20)$ & $0.45(0.18)$ & $0.44(0.18)$ & $0.37(0.21)$ \\
\hline
\end{tabular}

\# : divided by the Sanmenxia Dam

* : divided by the Three Gorges Dam

NA: no data available

\section{Discussion}

First, the performance of CryoSat-2 over inland water is discussed. Next, the comparison between surface water storage and terrestrial water storage is discussed at a regional scale followed by a discussion of water 'hotspot'.

\subsection{Performance of CryoSat-2 over inland water}

CryoSat-2 works pretty well over lakes in this study although the validation is conducted against very few lakes with ground truth. The RMSE is generally around $20 \mathrm{~cm}$ and is smaller for large lakes. This is in agreement with recent published result (Nielsen et al., 2017). On the other hand, the accuracy of river water level is good in terms of the RMSE in the order of $40 \mathrm{~cm}$. While as reported in section 3.4, the performance over the Yangtze River and Pearl River is relatively poor. Performance is worse over the downstream of the Yangtze River compared to the upstream. A possible reason for the poor performance is that waveforms are polluted by ships using the inland transport waterway. Waveforms show several peaks probably returning from different scatterers on the river (Fig. A1). One evidence is that the performance over a branch (i.e. Han river) of the Yangtze River is better even though river width is smaller (Table 4). This limitation suggests that 
384 more specific retracking or ad hoc outlier filtering algorithm are required for altimetry data 385 processing over heavily navigated rivers. Moreover, the relief impacts the data quality greatly. This 386 is due to the closed-loop tracking problem (Biancamaria et al., 2017; Dehecq et al., 2013). This is 387 quite clear from the upper part of Yangtze River and Yellow River in mountainous regions (Figs. $388 \quad 4$ and 5).

\section{$389 \quad$ 4.2. Effect of SWS on TWS}

Figure 8 illustrates the TWS changes observed by GRACE during the period of 2003-2016.

391 The three solutions from different centers agree relatively well, especially in region YGP (Fig. 8f).

392 Monthly TWS anomalies vary significantly among these five zones. IMX experienced a decreasing 393 trend although the fluctuation range is small (approx. $11 \mathrm{~mm}$ ) compared to YGP (Figs. 8c and 8f). 394 NPM had a special fluctuation pattern compared to other regions. Between 2008 and 2014, NPM 395 had twice large positive increases and two droughts in the TWS anomaly, which is likely related to 396 extreme precipitation and drought events (Cong et al., 2016) (see precipitation in Fig. B1). 397 Comparatively, TWS anomaly is the largest for YGP with a magnitude of $30 \mathrm{~mm}$ and shows a very 398 regular pattern (Fig. 8f). 


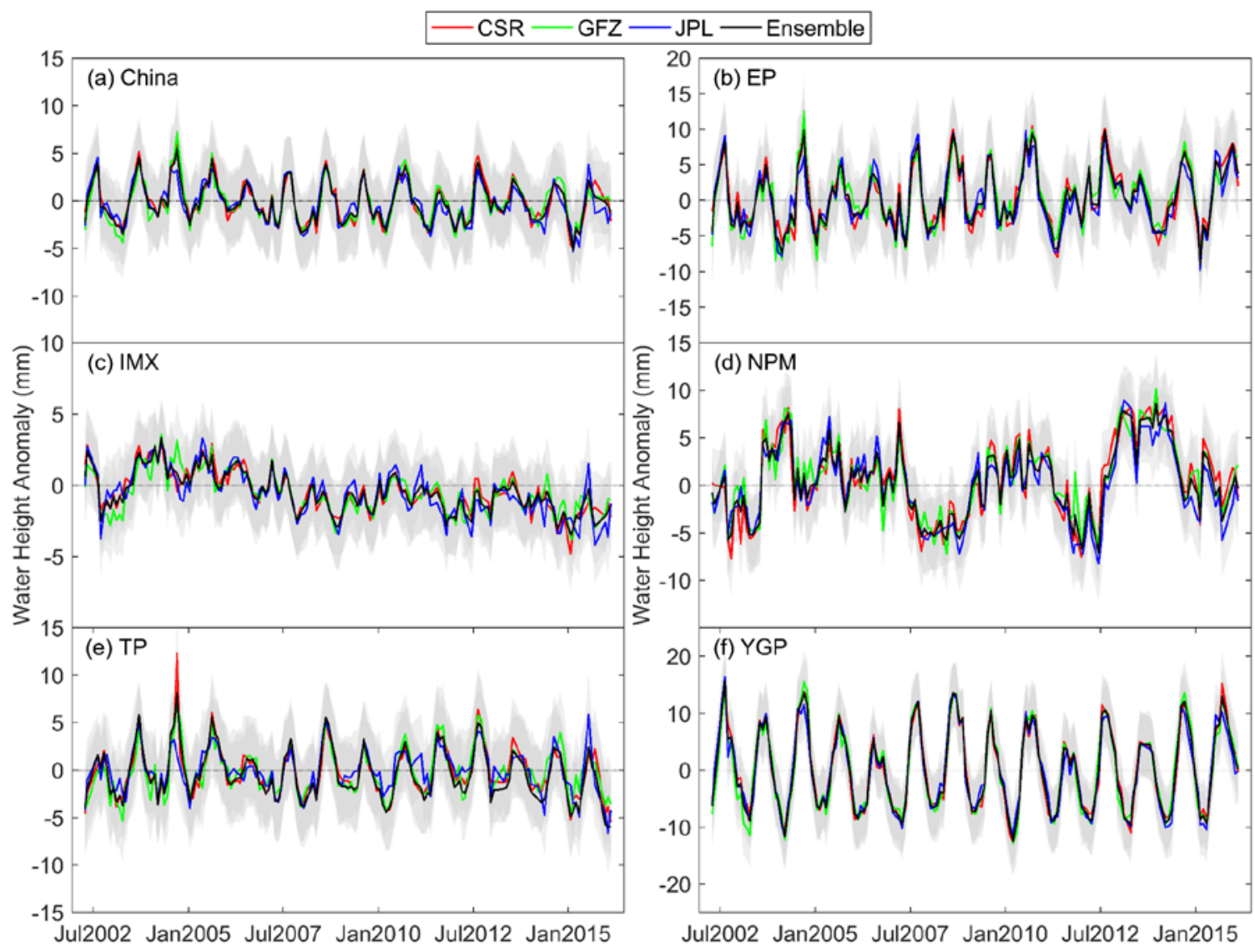

Fig. 8. Regionally averaged time series of equivalent water level anomalies with errors (grey shade) in different regions

403 pronounced TWS loss is the North China Plain, which is also reported by several studies (Feng et 404 al., 2013; Mo et al., 2016). Three regions of TWS increase are located in northern TP, northern 405 NPM, and south of EP, respectively. Among these, the average anomaly of the first hotspot (i.e. 406 northern TP) is $37.6 \mathrm{~mm}$ and the increasing rate is $11.9 \mathrm{~mm} / \mathrm{yr}$. Moreover, the north of NPM and 407 the south of EP also have net accumulation in TWS, and the corresponding increasing rates are 6.9 408 and $10.9 \mathrm{~mm} / \mathrm{yr}$, respectively (see the map of TWS change in Fig. C1).

409 On a regional scale, the contributions of SWS to TWS are relatively small for IMX and EP, 410 although in the latter 204 lakes and reservoirs are investigated. It indicates that the changes of water 411 bodies are very inhomogeneous, and cancel each other out to produce negligible net effect (Fig. 9a 
and Table 2). Moreover, the change rates of SWS and TWS in all zones except YGP are opposite.

413 Especially in TP, the SWS increment effectively mitigates total storage loss.

On the other hand, SWS changes agree well with TWS changes in northwest and central IMX, 415 and regions around the Bohai Bay Rim, where both are decreasing (Fig. 9b). In central IMX, i.e. 416 the Inner Mongolia, lakes are shrinking and the number of lakes is also decreasing according to 417 Tao et al (2015), who attributed it to intensive human activities (e.g. coal mining) as well as drier 418 and warmer climate.

(a)

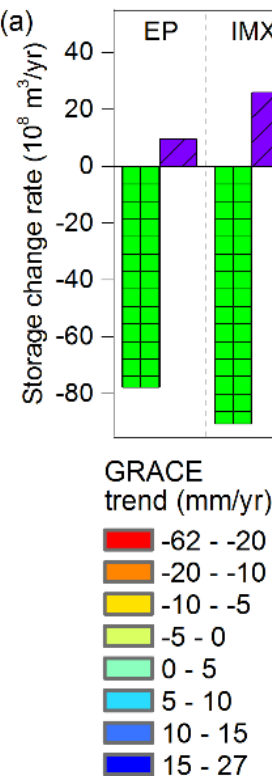

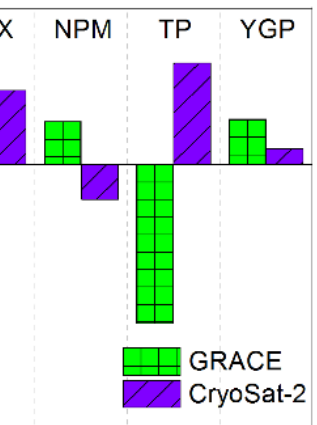

CryoSat-2

Altimetry

trend $(\mathrm{m} / \mathrm{yr})$

$Y<-1.0$

r $-0.9--0.1$

$r-0.1-0$

A $0.1-0.5$

A $0.6-1.0$

A $>1.0$

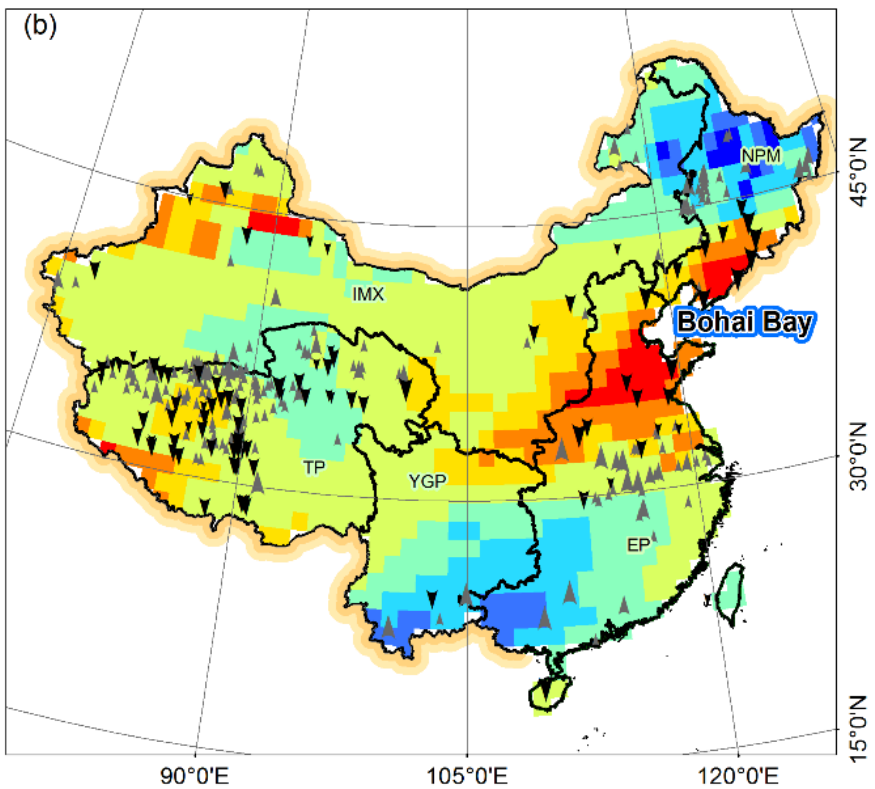

Fig. 9. Storage change rates by zones (a) and distribution of the changing trend of water level (b) (only 288 with a significant trend shown) inferred from GRACE and altimetry for the period of 2010 - 2016

As an important part of SWS, reservoir storage change has a marked impact on TWS change

423 at national scale (Fig. 10). For certain years, both reservoir storage change and TWS change have

424 the same pattern, i.e. increase or decrease, and even similar magnitude for 2006 and 2010, which

425 means that the reservoir storage changes dominated the TWS change. 


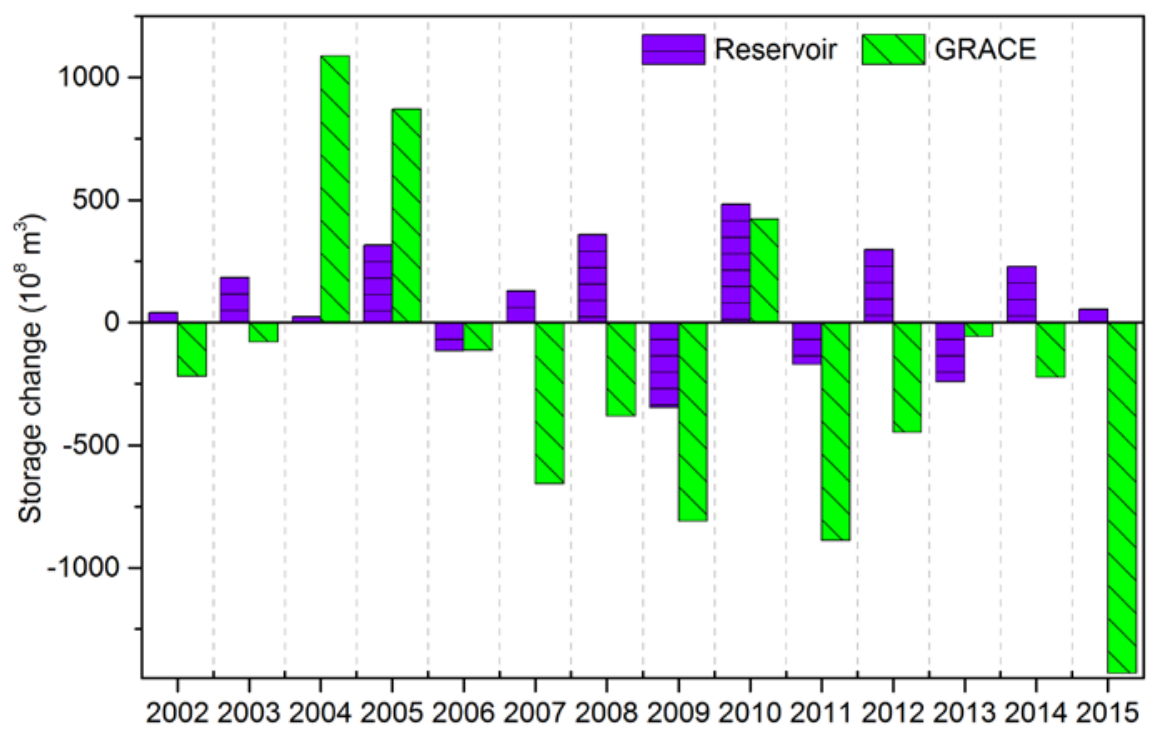

Fig. 10. Comparison of annual changes between reservoir storage and TWS at national scale

428 Therefore, SWS should not be ignored when estimating groundwater storage change from

429 GRACE especially in the areas with significant lake and reservoir storage.

\section{4.3. Hotspots showing significant surface water dynamics}

431 As mentioned before, water storage is rapidly changing in some hotspots in China (Fig. 11).

432 We will discuss the variations in SWS and TWS for eight hotspot regions below. 


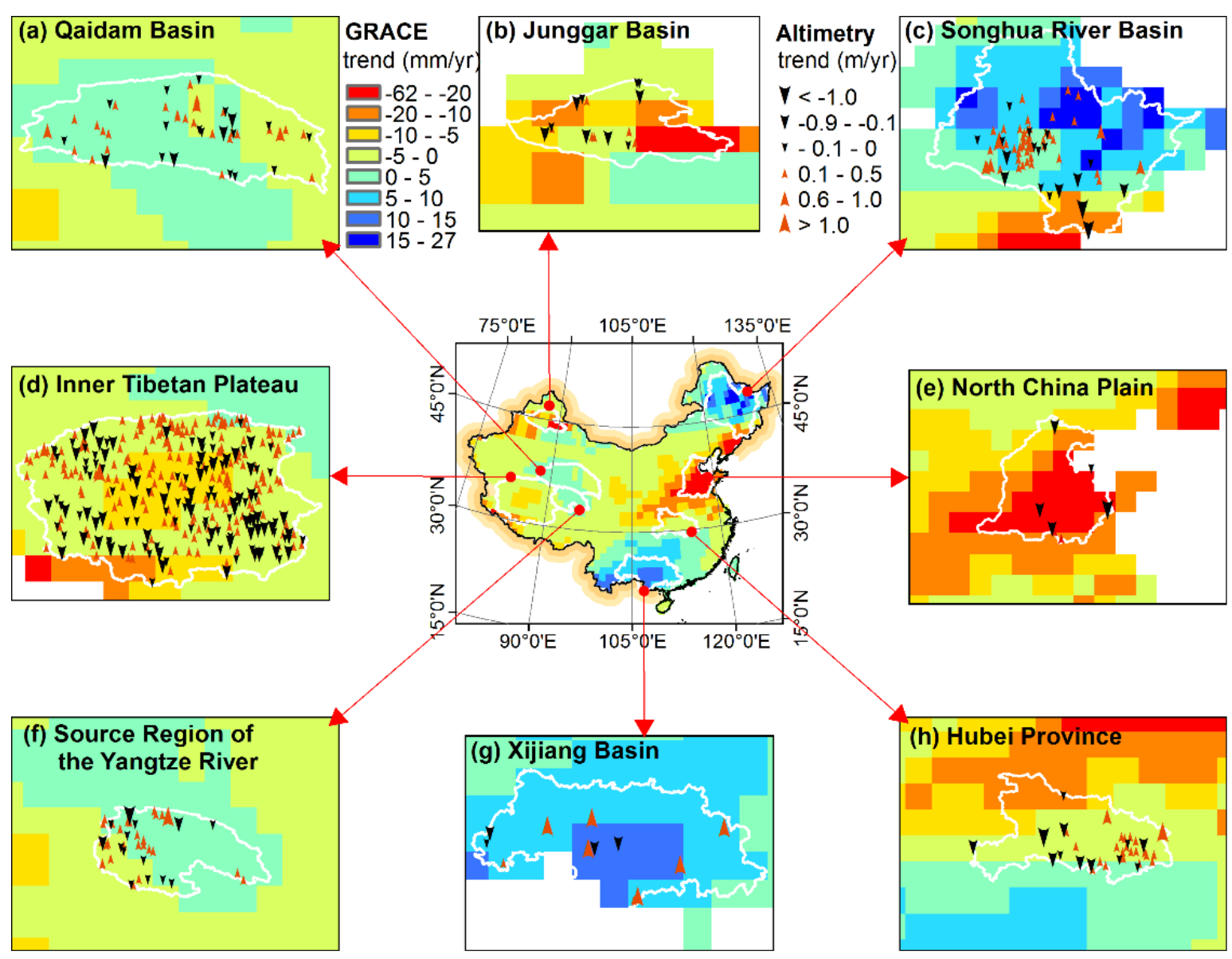

433

434

435

436

437

438

439

440

441

442

443

444

445

Fig. 11. Hotspots of regional storage change over the period of 2010-2016.

Qaidam Basin: Although the lakes in Qaidam Basin do not show uniform rising (Fig. 11a), nine of the 12 large lakes $\left(>100 \mathrm{~km}^{2}\right)$ are expanded. Therefore, the net SWS change is positive.

However, the TWS change is very small during 2010-2016 (Figs. 11a and 12a); that is, other storage components (e.g. soil moisture storage, groundwater storage, snow, and ice, etc.) are decreasing at the similar rate as lake storage increasing. Thus, the SWS contribution is nearly $50 \%$ of TWS change. This is different from previous study where the contribution from lakes is estimated as $1.1 \%$ during 2003 - 2012 (Jiao et al., 2015).

Inner Tibetan Plateau: TWS change during 2010-2016 is different from that during 2003-2009 in Inner Tibetan Plateau, i.e. the increasing rate slowed down and even reversed (Fig. 12d). Contrary to TWS, SWS do not show a significant difference between these two periods (35.5 vs $\left.50.4 \times 10^{8} \mathrm{~m}^{3} / \mathrm{yr}\right)$. It is interesting that TWS has been decreasing over the recent six years while 
SWS has been increasing (Fig. 12d). This may be due to acceleration of glaciers/snowpack melting

447 or groundwater storage change. According to Xiang et al (2016), groundwater storage has been

448 increasing during the period 2003-2009. If we assume that groundwater is steady after 2009, glacial

449 melt must have contributed large storage losses $\left(-68.9 \times 10^{8} \mathrm{~m}^{3} / \mathrm{yr}\right)$. Besides, permafrost and talik

450 are developed in this region, which affect soil moisture and groundwater (Muskett and Romanovsky,

451 2011). However, it is beyond the scope of this study to explain this variation. Nevertheless, lake

452 storage is an important component affecting TWS variation in this region.
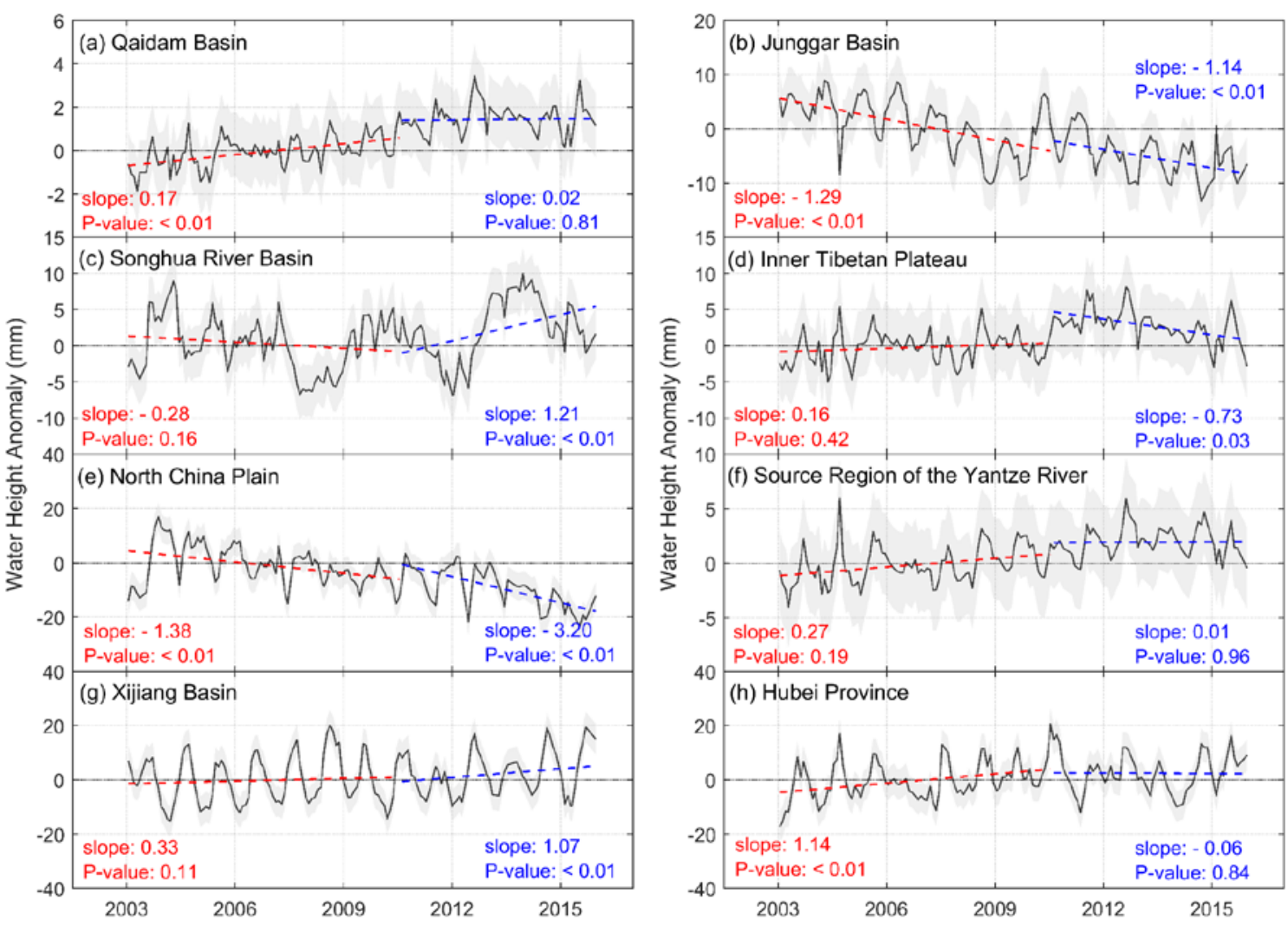

Fig. 12. Monthly changes of TWS for eight hotspots during two periods, i.e. Apr. 2002- Dec. 2009 and Jan. 2010- Feb. 2016

SRYR: Lakes in SRYR have risen at a mean rate of $0.1 \mathrm{~m} / \mathrm{yr}$ recently. However, the surplus of TWS is a bit smaller than SWS (Fig. 13). The case is the same as that in Qaidam Basin where

458 SWS was increasing while TWS was decreasing slightly (Fig. 13).

Inner TP, Qaidam Basin, and SRYR all show that SWS is increasing but TWS is not increasing as much as SWS or even decreasing. It appears that groundwater storage in these areas is decreasing. 
461 Actually, however, groundwater storage in this region is increasing during the period of 2003-2009 462 and the change is attributed to increased runoff recharge from melt water/precipitation (Xiang et 463 al., 2016).

Junggar Basin and North China Plain are two hotspots showing consistent decline in TWS during 2003-2016 (Figs. 11b, 11e and 12b, 12e), and in the recent six years, the declining rates are $466-11.8 \pm 2.4$ and $-20.0 \pm 3.5 \mathrm{~mm} / \mathrm{yr}$, respectively. However, for the former, SWS is decreasing 467 although the contribution is very small due to limited number of lakes in this region (Fig. 12); thus 468 TWS change is dominated by groundwater variation considering the very dry climate. This decrease 469 is mainly caused by excessive extraction for piedmont agriculture (Zhao et al., 2015). Similarly, in 470 North China Plain, SWS changes affect TWS variation very slightly, and the TWS change is mainly 471 attributed to the groundwater over-exploitation (Shi et al., 2011).

472 TWS in Songhua River Basin has experienced several abrupt changes which are plausibly 473 related to extreme precipitation events and droughts. In this region, although lakes exhibit slight 474 increasing trends (Fig. 11c), SWS is declining owing to the decline of large reservoirs (Fig. B1). 475 The declining rate of reservoir storage $\left(-1.4 \times 10^{8} \mathrm{~m}^{3} / \mathrm{yr}\right)$ is almost the same as SWS estimated from 476 CryoSat-2, which indicates that SWS change is dominated by reservoir storage. Water storage 477 depends directly on precipitation in this region. This is justified by the fact that TWS change has 478 very similar pattern to precipitation and total water resource given in the water resources Bulletin 479 (http://www.slwr.gov.cn/) (Fig. B1). TWS from GRACE and total water resource from Bulletin 480 both show a sharp peak in 2013, which is caused by the extreme precipitation in the summer of 481 2013. This is verified by Wang et al. (2015) who found a considerable increase in groundwater 482 tables after the flood event. One interesting finding is that GRACE disagrees with the total water 483 resource Bulletin record and precipitation for 2004 (Fig. B1).

484 In the south China, Xijiang Basin, main part of Pearl River (c.a. 78\%) shows a slight increase 485 in TWS, especially during 2010-2016 at a rate of $8.6 \mathrm{~mm} / \mathrm{yr}$ (Fig. 12g). The estimated SWS 

and SWS increase (Fig. 13). Due to human activities, lakes in Hubei have sharply decreased both 488 in area and size during the past century (Zhang et al., 2009). However, lake storage has a small 489 effect on TWS compared with reservoirs, such as Three Gorges Reservoir $\left(393 \times 10^{8} \mathrm{~m}^{3}\right)$ and 490 Huanglongtan Reservoir (capacity $12.3 \times 10^{8} \mathrm{~m}^{3}$ ). Overall, SWS is increasing and playing a positive 491 role in maintaining the TWS balance.

492

493

494

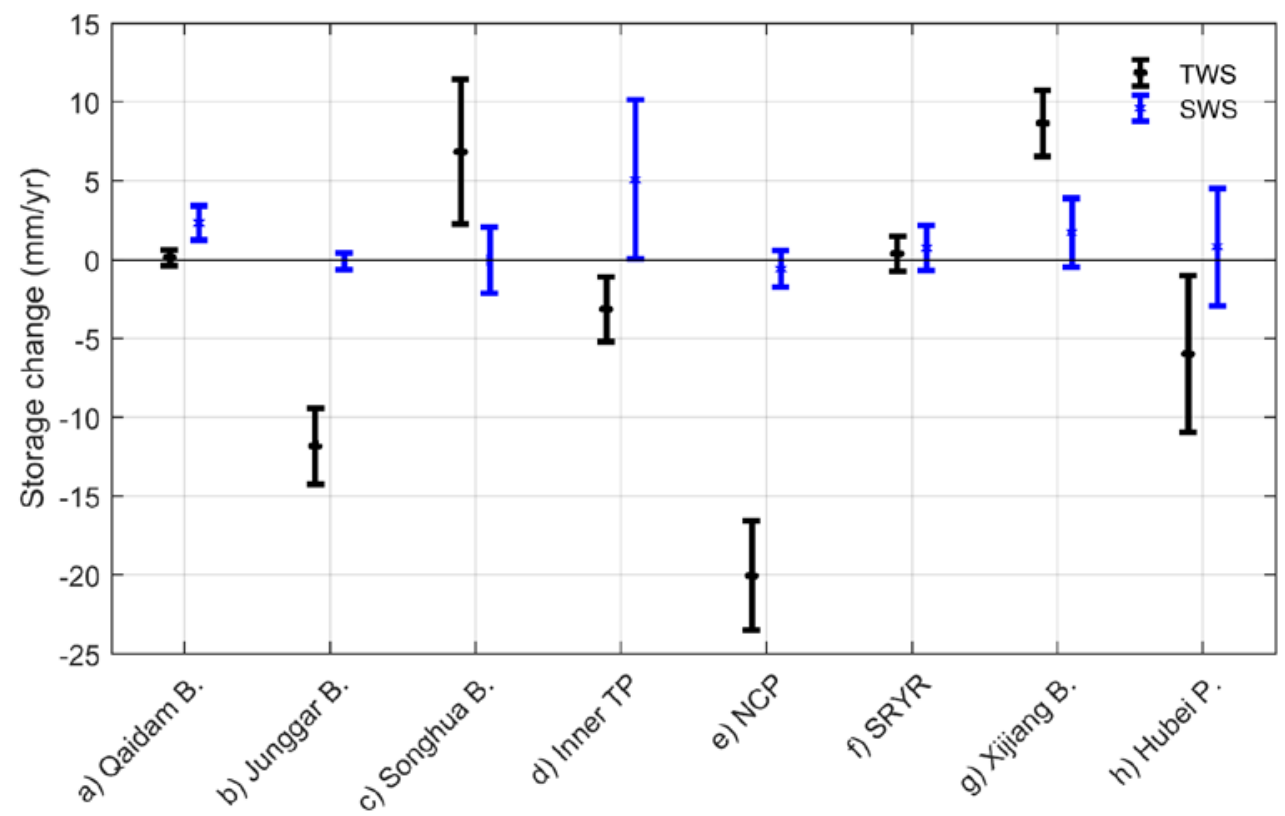

Fig. 13. TWS and SWS changes in eight hotspots during 2010-2016

\section{Summary and Conclusions}

In this study, the value of CryoSat-2 for monitoring surface water at a national scale for China is exploited. We (a) construct the water level time series of lakes and reservoirs in China at a national scale; (b) assess the spatial variation of surface water bodies; (c) validate the performance of CryoSat-2 over 6 rivers; (d) estimate the surface water storage changes and evaluated its impact on terrestrial water storage change.

Water level variations of 1163 lakes and reservoirs across China during 2010 and 2016 are investigated with CryoSat-2 data. The results show that 288 water bodies show a significant 
502 changing trend. Water level of lakes varies regionally, specifically, water bodies in Junggar Basin

503 and Huai River Basin show a dominant declining trend. In contrast, those in Songnen Plain, lower

504 Yangtze River basin, and north Tibetan Plateau show a marked rising trend. And the rising rate is

505 far beyond of the declining rate in the north Tibetan Plateau.

506 Six large rivers are investigated and the CryoSat-2 derived water level generally agree well 507 with in-situ measurements, especially for the Yellow River, Songhua River, and Heilongjiang508 Amur River with RMSE values ranging from 0.22 to $0.6 \mathrm{~m}, 0.22$ to $0.5 \mathrm{~m}$, and 0.24 to $0.35 \mathrm{~m}$, 509 respectively. Comparatively, data quality over the Yangtze River and Pearl River is poor because 510 of the widely-distributed ships and the rugged topography.

511 The estimated surface water storage changes in Tibetan Plateau, and Inner Mongolia and 512 Xinjiang are 35.5 and $25.9 \times 10^{8} \mathrm{~m}^{3} / \mathrm{yr}$, respectively. On the contrary, Northeast Plain and Mountain 513 zone exhibited a decline. Surface water storage is one important component to TWS change, and 514 plays an non-negligible role in TWS change, for instance, in the Tibetan Plateau and the Qaidam 515 basin.

516 CryoSat-2 has great value for monitoring surface water bodies. It outperforms previous radar 517 altimetry missions in terms of spatial coverage and resolution (SAR and SARIn modes). Besides, 518 the performance of LRM is comparable to SAR and SARIn modes in terms of RMSE against in519 situ data. However, new method is required to derive valid water levels for heavily navigated rivers 520 such as the Yangtze and Pearl Rivers in China.

\section{Acknowledgements}

522 We wish to thank Dr. Jiaxu Liu for supporting hydrometric data collection. We thank Raphael 523 Schneider for many helpful discussions and input. ESA and NASA/JPL are acknowledged for 524 providing CryoSat-2 data and GRACE data. We also want to thank Editor Aida Alvera-Azcarate 
525 and the three anonymous reviewers for their valuable comments. The first author is funded by China

526 Scholarship Council, which is greatly acknowledged.

527 Appendix A Illustration of polluted waveforms over the Yangtze River
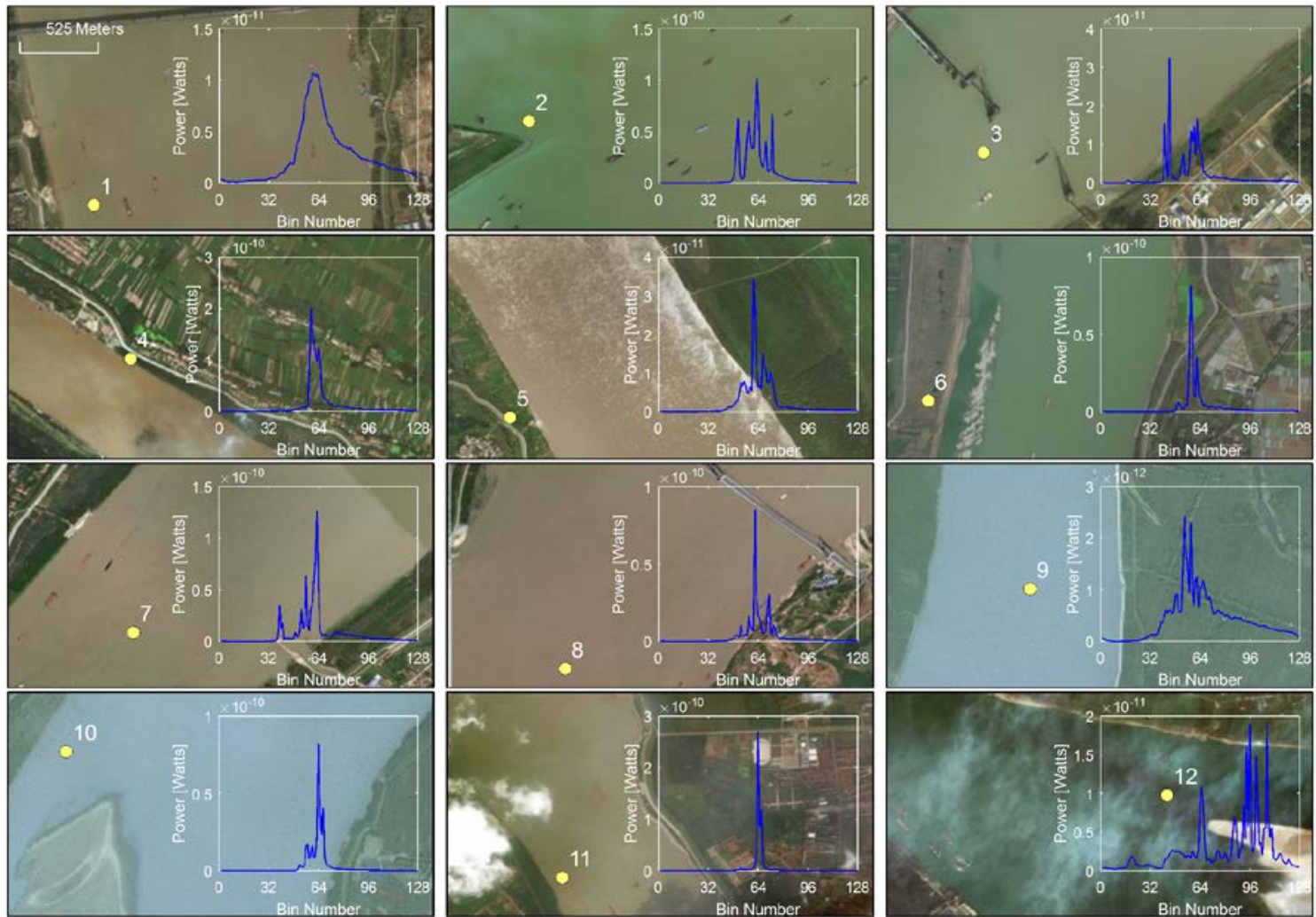

Fig. A1. Multi-peak waveforms (20 Hz) from the lower Yangtze River 

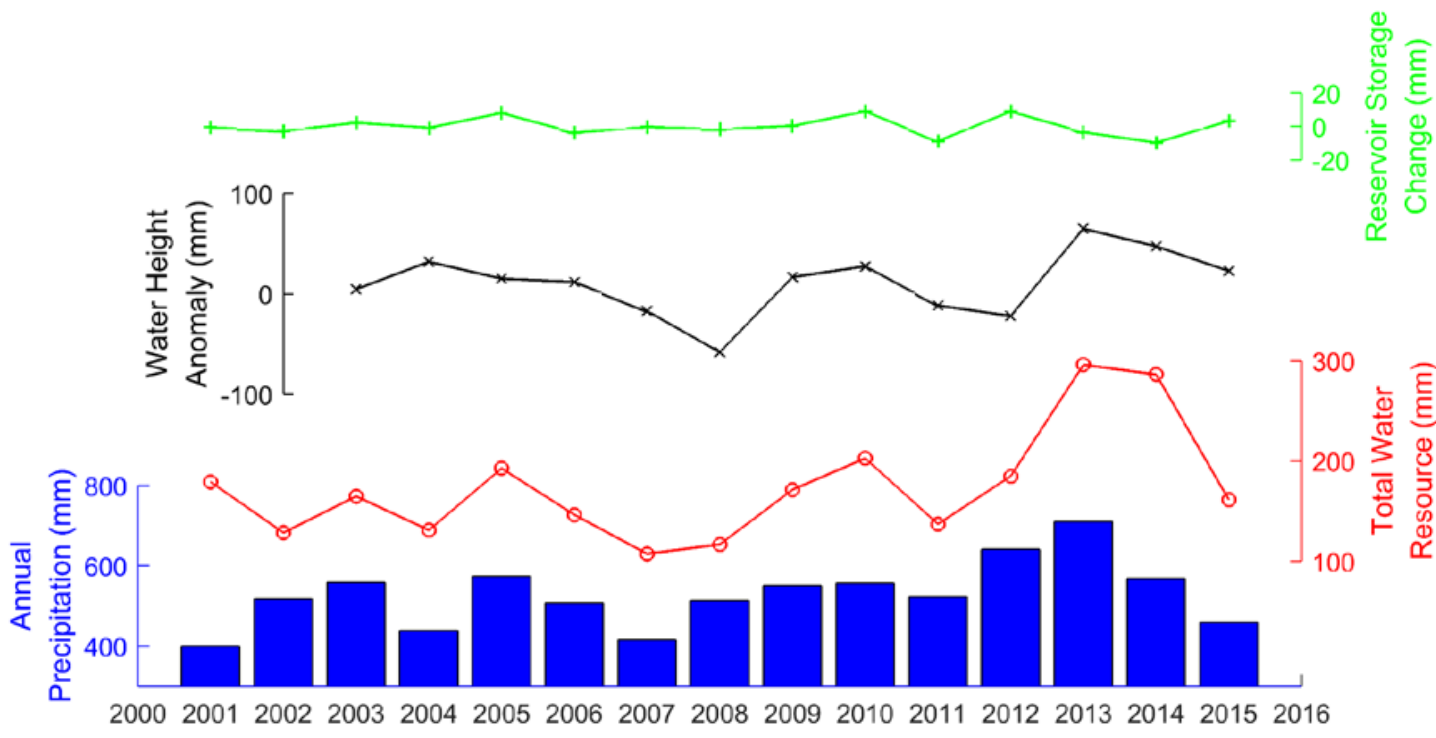

534 Appendix C Comparison between surface water storage change derived from CryoSat-2 and 535

Fig. B1. Variations of annual precipitation amount (blue bar), reservoir storage change (in green), total water resource (in red) and TWS anomaly (in black) from GRACE in Songhua River Basin terrestrial water storage change over the period of 2003 - 2016 from GRACE

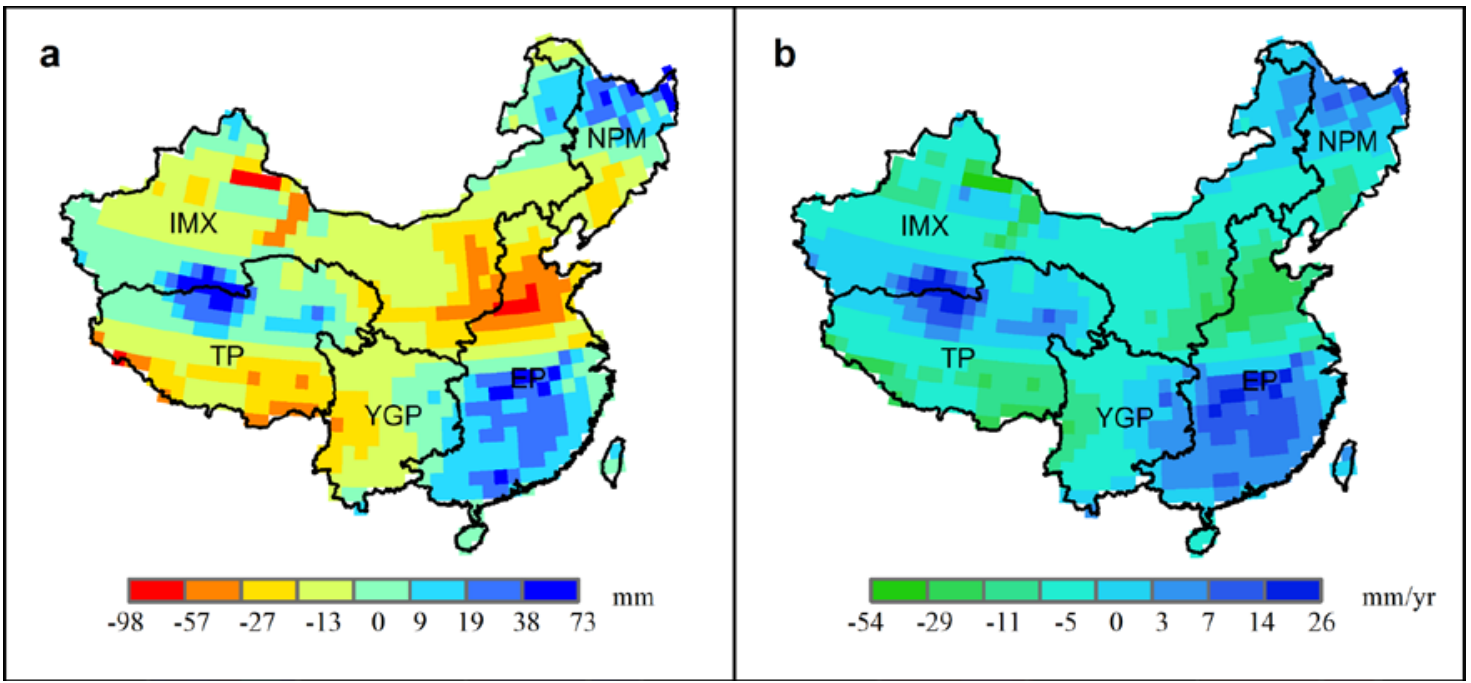

Fig. C1. Equivalent water level anomalies from ensemble mean of CSR, GFZ and JPL. (a) Multi-year average (climatology) and (b) change rate, over the period of 2003 - 2016

Appendix D Some lakes with large storage change

Table D1. Lakes with a larger storage change rate 


\begin{tabular}{ccccc}
\hline Lake & Area & Region & $\begin{array}{c}\text { Level change rate } \\
(\mathrm{m} / \mathrm{yr})\end{array}$ & $\begin{array}{c}\text { Storage change } \\
\text { rate }\left(10^{8} \mathrm{~m}^{3} / \mathrm{yr}\right)\end{array}$ \\
\hline Hulun Lake & 2190 & IMX & $0.68 \pm 0.15$ & $15.0 \pm 3.2$ \\
Aqqikkol Lake & 537 & IMX & $0.59 \pm 0.03$ & $3.1 \pm 1.5$ \\
Ayakkum Lake & 899 & IMX & $0.28 \pm 0.03$ & $2.5 \pm 0.3$ \\
Siling Co & 2393 & TP & $0.21 \pm 0.04$ & $4.9 \pm 1.0$ \\
Qinghai Lake & 4357 & TP & $0.18 \pm 0.02$ & $7.8 \pm 0.7$ \\
Migriggyangzham Co & 541 & TP & $0.41 \pm 0.07$ & $2.3 \pm 0.4$ \\
Dorsoidong Co & 490 & TP & $0.39 \pm 0.05$ & $1.9 \pm 0.2$ \\
Dogaicoring Qangco & 400 & TP & $0.39 \pm 0.05$ & $1.9 \pm 0.3$ \\
Dagze Co & 315 & TP & $0.38 \pm 0.07$ & $1.2 \pm 0.2$ \\
Charol Tso & 390 & TP & $0.33 \pm 0.06$ & $1.3 \pm 0.2$ \\
Yamdrok Lake & 558 & TP & $-0.22 \pm 0.08$ & $-1.2 \pm 0.4$ \\
Taro Co & 488 & TP & $-0.21 \pm 0.04$ & $-1.0 \pm 0.2$ \\
\hline
\end{tabular}

References

544

545

546

547

548

549

550

551

552

553

554

555

556

557

558

559

560

561

562

563

564

565

566

567

568

569

570

Bercher, N., Dinardo, S., Lucas, B.M., Fleury, S., Calmant, S., Crétaux, J.-F., Femenias, P., Boy, F., Picot, N., Benveniste, J., 2013. Applications of CryoSat-2 SAR \& SARIn modes for the monitoring of river water levels. Proc. CryoSat Third User Work. 12 - 14 March 2013 1-7.

Berry, P.A.M., Garlick, J.D., Freeman, J.A., Mathers, E.L., 2005. Global inland water monitoring from multi-mission altimetry. Geophys. Res. Lett. 32, 1-4. doi:10.1029/2005GL022814

Biancamaria, S., Frappart, F., Leleu, A.-S., Marieu, V., Blumstein, D., Desjonquères, J.-D., Boy, F., Sottolichio, A., Valle-Levinson, A., 2017. Satellite radar altimetry water elevations performance over a 200m wide river: Evaluation over the Garonne River. Adv. Sp. Res. 59, 128-146. doi:10.1016/j.asr.2016.10.008

Birkett, C.M., 1995. The contribution of TOPEX/POSEIDON to the global monitoring of climatically sensitive lakes. J. Geophys. Res. 100, 25179. doi:10.1029/95JC02125

Birkinshaw, S.J., O’Donnell, G.M., Moore, P., Kilsby, C.G., Fowler, H.J., Berry, P.A.M., 2010. Using satellite altimetry data to augment flow estimation techniques on the Mekong River. Hydrol. Process. 24, 3811-3825. doi:10.1002/hyp.7811

Carroll, M.L., Townshend, J.R., DiMiceli, C.M., Noojipady, P., Sohlberg, R.A., 2009. A new global raster water mask at 250 m resolution. Int. J. Digit. Earth 2, 291-308. doi:10.1080/17538940902951401

Cheng, M., Ries, J.C., Tapley, B.D., 2011. Variations of the Earth's figure axis from satellite laser ranging and GRACE. J. Geophys. Res. Solid Earth 116, 1-14. doi:10.1029/2010JB000850

Cong, D., Zhao, S., Li, X., Zhuang, X., Chen, C., 2016. Temporal and spatial distribution of drought in Northeast China based on temperature vegetation drought index (TVDI) from 2001-2013. Int. Geosci. Remote Sens. Symp. 2016-Novem, 4241-4244. doi:10.1109/IGARSS.2016.7730105

Crétaux, J.-F., Abarca-del-Río, R., Bergé-Nguyen, M., Arsen, A., Drolon, V., Clos, G., Maisongrande, P., 2016. Lake Volume Monitoring from Space. Surv. Geophys. 37, 269305. doi:10.1007/s10712-016-9362-6

Crétaux, J., Biancamaria, S., Arsen, A., Bergé-nguyen, M., Becker, M., 2015. Global surveys of 
reservoirs and lakes from satellites and regional application to the Syrdarya river basin. Environ. Res. Lett. 10, 15002. doi:10.1088/1748-9326/10/1/015002

Dehecq, A., Gourmelen, N., Shepherd, A., Cullen, R., Trouvé, E., 2013. Evaluation of CryoSat-2 for height retrieval over the Himalayan range, in: CryoSat-2 Third User Workshop, March 2013. Dresden, Germany.

European Space Agency, Mullar Space Science Laboratory, 2012. CryoSat Product Handbook.

Feng, W., Zhong, M., Lemoine, J.M., Biancale, R., Hsu, H.T., Xia, J., 2013. Evaluation of groundwater depletion in North China using the Gravity Recovery and Climate Experiment (GRACE) data and ground-based measurements. Water Resour. Res. 49, 2110-2118. doi:10.1002/wrcr.20192

Forootan, E., Rietbroek, R., Kusche, J., Sharifi, M.A., Awange, J.L., Schmidt, M., Omondi, P., Famiglietti, J., 2014. Separation of large scale water storage patterns over Iran using GRACE, altimetry and hydrological data. Remote Sens. Environ. 140, 580-595. doi:10.1016/j.rse.2013.09.025

Gao, H., Birkett, C., Lettenmaier, D.P., 2012. Global monitoring of large reservoir storage from satellite remote sensing. Water Resour. Res. 48. doi:10.1029/2012WR012063

Global Water Partnership, 2015. China's water resources management challenge: The "Three Red Lines.” doi:10.1017/CBO9781107415324.004

Jain, M., Andersen, O.B., Dall, J., Stenseng, L., 2015. Sea surface height determination in the Arctic using Cryosat-2 SAR data from primary peak empirical retrackers. Adv. Sp. Res. 55, 40-50. doi:10.1016/j.asr.2014.09.006

Jarvis, A., Reuter, H.I., Nelson, A., Guevara, E., 2008. Hole-filled SRTM for the globe Version 4 [WWW Document]. URL http://srtm.csi.cgiar.org (accessed 6.8.17).

Jiang, L., Nielsen, K., Andersen, O.B., Bauer-Gottwein, P., 2017a. Monitoring recent lake level variations on the Tibetan Plateau using CryoSat-2 SARIn mode data. J. Hydrol. 544, 109124. doi:10.1016/j.jhydrol.2016.11.024

Jiang, L., Schneider, R., Andersen, O.B., Bauer-Gottwein, P., 2017b. CryoSat-2 altimetry applications over rivers and lakes. Water 9, 1-20. doi:10.3390/w9030211

Jiang, Y., 2009. China’s water scarcity. J. Environ. Manage. 90, 3185-3196. doi:10.1016/j.jenvman.2009.04.016

Jiao, J.J., Zhang, X., Liu, Y., Kuang, X., 2015. Increased water storage in the Qaidam Basin, the North Tibet Plateau from GRACE Gravity Data. PLoS One 10, 1-12. doi:10.1371/journal.pone.0141442

Keith Raney, R., 1998. The delay/doppler radar altimeter. IEEE Trans. Geosci. Remote Sens. 36, 1578-1588. doi:10.1109/36.718861

Lai, X., Jiang, J., Liang, Q., Huang, Q., 2013. Large-scale hydrodynamic modeling of the middle Yangtze River Basin with complex river-lake interactions. J. Hydrol. 492, 228-243. doi:10.1016/j.jhydrol.2013.03.049

Landerer, F.W., Swenson, S.C., 2012. Accuracy of scaled GRACE terrestrial water storage estimates. Water Resour. Res. 48, 1-11. doi:10.1029/2011WR011453

Liu, J., Yang, W., 2012. Water Sustainability for China and Beyond. Science (80-. ). 337, 649650. doi:10.1126/science.1219471

Longuevergne, L., Wilson, C.R., Scanlon, B.R., Crétaux, J.F., 2013. GRACE water storage estimates for the middle east and other regions with significant reservoir and lake storage. Hydrol. Earth Syst. Sci. 17, 4817-4830. doi:10.5194/hess-17-4817-2013

Ma, R., Duan, H., Hu, C., Feng, X., Li, A., Ju, W., Jiang, J., Yang, G., 2010. A half-century of changes in China's lakes: Global warming or human influence? Geophys. Res. Lett. 37.

Ma, R.H., Yang, G.S., Duan, H.T., Jiang, J.H., Wang, S.M., Feng, X.Z., Li, A.N., Kong, F.X., Xue, B., Wu, J.L., Li, S.J., 2011. China's lakes at present: Number, area and spatial distribution. Sci. China Earth Sci. 54, 283-289. doi:10.1007/s11430-010-4052-6

Michailovsky, C.I., McEnnis, S., Berry, P. a M., Smith, R., Bauer-Gottwein, P., 2012. River 
monitoring from satellite radar altimetry in the Zambezi River basin. Hydrol. Earth Syst. Sci. 16, 2181-2192. doi:10.5194/hess-16-2181-2012

Ministry of Water Resources, P.R.C., 2013. Bulletin of First National Census for Water.

Mo, X., Wu, J.J., Wang, Q., Zhou, H., 2016. Variations in water storage in China over recent decades from GRACE observations and GLDAS. Nat. Hazards Earth Syst. Sci. 16, 469482. doi:10.5194/nhess-16-469-2016

Moore, P., Williams, S.D.P., 2014. Integration of altimetric lake levels and GRACE gravimetry over Africa: Inferences for terrestrial water storage change 2003-2011. Water Resour. Res. 50, 9696-9720. doi:10.1002/2014WR015506

Muala, E., Mohamed, Y.A., Duan, Z., van der Zaag, P., 2014. Estimation of reservoir discharges from Lake Nasser and Roseires Reservoir in the Nile Basin using satellite altimetry and imagery data. Remote Sens. 6, 7522-7545. doi:10.3390/rs6087522

Muskett, R.R., Romanovsky, V.E., 2011. Alaskan Permafrost groundwater storage changes derived from GRACE and ground measurements. Remote Sens. 3, 378-397. doi:10.3390/rs3020378

MWR, 2014. China Water Statistical Yearbook. China Water Power Press, Beijing.

Ndehedehe, C.E., Agutu, N.O., Okwuashi, O., Ferreira, V.G., 2016. Spatio-Temporal Variability of Droughts and Terrestrial Water Storage over Lake Chad Basin using Independent Component Analysis. J. Hydrol. 540, 106-128. doi:10.1016/j.jhydrol.2016.05.068

Nielsen, K., Stenseng, L., Andersen, O.B., Knudsen, P., 2017. The Performance and Potentials of the CryoSat-2 SAR and SARIn Modes for Lake Level Estimation. Water 9, 374. doi:10.3390/w9060374

Nielsen, K., Stenseng, L., Andersen, O.B., Villadsen, H., Knudsen, P., 2015. Validation of CryoSat-2 SAR mode based lake levels. Remote Sens. Environ. 171, 162-170. doi:10.1016/j.rse.2015.10.023

Papa, F., Frappart, F., Malbeteau, Y., Shamsudduha, M., Vuruputur, V., Sekhar, M., Ramillien, G., Prigent, C., Aires, F., Pandey, R.K., Bala, S., Calmant, S., 2015. Satellite-derived surface and sub-surface water storage in the Ganges-Brahmaputra River Basin. J. Hydrol. Reg. Stud. doi:10.1016/j.ejrh.2015.03.004

Papa, F., Prigent, C., Aires, F., Jimenez, C., Rossow, W.B., Matthews, E., 2010. Interannual variability of surface water extent at the global scale, 1993-2004. J. Geophys. Res. 115, D12111. doi:10.1029/2009JD012674

Pekel, J.-F., Cottam, A., Gorelick, N., Belward, A.S., 2016. High-resolution mapping of global surface water and its long-term changes. Nature 1-19. doi:10.1038/nature20584

Piao, S., Ciais, P., Huang, Y., Shen, Z., Peng, S., Li, J., Zhou, L., Liu, H., Ma, Y., Ding, Y., Friedlingstein, P., Liu, C., Tan, K., Yu, Y., Zhang, T., Fang, J., 2010. The impacts of climate change on water resources and agriculture in China. Nature 467, 43-51. doi:10.1038/nature09364

Qiu, J., 2010. China faces up to groundwater crisis. Nature 466, 308. doi:10.1038/466308a

Schneider, R., Godiksen, P.N., Villadsen, H., Madsen, H., Bauer-Gottwein, P., 2017. Application of CryoSat-2 altimetry data for river analysis and modelling. Hydrol. Earth Syst. Sci. 21, 751-764. doi:10.5194/hess-21-751-2017

Schwatke, C., Dettmering, D., Bosch, W., Seitz, F., 2015. DAHITI - An innovative approach for estimating water level time series over inland waters using multi-mission satellite altimetry. Hydrol. Earth Syst. Sci. 19, 4345-4364. doi:10.5194/hess-19-4345-2015

Shi, J., Wang, Z., Zhang, Z., Fei, Y., Li, Y., Zhang, F., Chen, J., Qian, Y., 2011. Assessment of deep groundwater over-exploitation in the North China Plain. Geosci. Front. 2, 593-598. doi:10.1016/j.gsf.2011.07.002

Song, C., Huang, B., Ke, L., 2013. Modeling and analysis of lake water storage changes on the Tibetan Plateau using multi-mission satellite data. Remote Sens. Environ. 135, 25-35. doi:10.1016/j.rse.2013.03.013 
Sulistioadi, Y.B., Tseng, K.-H., Shum, C.K., Hidayat, H., Sumaryono, M., Suhardiman, A., Setiawan, F., Sunarso, S., 2015. Satellite radar altimetry for monitoring small rivers and lakes in Indonesia. Hydrol. Earth Syst. Sci. 19, 341-359. doi:10.5194/hess-19-341-2015 SWBD, 2003. Shuttle Radar Topography Mission Water Body Dataset [WWW Document]. URL https://lta.cr.usgs.gov/srtm_water_body_dataset (accessed 6.8.17).

Swenson, S., Chambers, D., Wahr, J., 2008. Estimating geocenter variations from a combination of GRACE and ocean model output. J. Geophys. Res. Solid Earth 113, 1-12. doi:10.1029/2007JB005338

Tao, S., Fang, J., Zhao, X., Zhao, S., Shen, H., Hu, H., Tang, Z., Wang, Z., Guo, Q., 2015. Rapid loss of lakes on the Mongolian Plateau. Proc. Natl. Acad. Sci. 112, 2281-2286. doi:10.1073/pnas.1411748112

Villadsen, H., Andersen, O.B., Stenseng, L., 2014. Annual cycle in lakes and rivers from CryoSat-2 altimetry - The Brahmaputra river. Int. Geosci. Remote Sens. Symp. 894-897. doi:10.1109/IGARSS.2014.6946569

Villadsen, H., Andersen, O.B., Stenseng, L., Nielsen, K., Knudsen, P., 2015. CryoSat-2 altimetry for river level monitoring - Evaluation in the Ganges-Brahmaputra basin. Remote Sens. Environ. 168, 80-89. doi:10.1016/j.rse.2015.05.025

Villadsen, H., Deng, X., Andersen, O.B., Stenseng, L., Nielsen, K., Knudsen, P., 2016. Improved inland water levels from SAR altimetry using novel empirical and physical retrackers. J. Hydrol. 537, 234-247. doi:10.1016/j.jhydrol.2016.03.051

Wang, L., Yao, Z.-J., Jiang, L.-G., Wang, R., Wu, S.-S., Liu, Z.-F., 2016. Changes in Climate Extremes and Catastrophic Events in the Mongolian Plateau from 1951 to 2012. J. Appl. Meteorol. Climatol. 55, 1169-1182. doi:10.1175/JAMC-D-14-0282.1

Wang, S., Dou, H., 1998. Lakes in China. Science Press, Beijing.

Wang, X., Zhang, G., Xu, Y.J., 2015. Impacts of the 2013 extreme flood in Northeast China on regional groundwater depth and quality. Water 7, 4575-4592. doi:10.3390/w7084575

Wingham, D.J., Francis, C.R., Baker, S., Bouzinac, C., Brockley, D., Cullen, R., de ChateauThierry, P., Laxon, S.W., Mallow, U., Mavrocordatos, C., Phalippou, L., Ratier, G., Rey, L., Rostan, F., Viau, P., Wallis, D.W., 2006. CryoSat: A mission to determine the fluctuations in Earth's land and marine ice fields. Adv. Sp. Res. 37, 841-871. doi:10.1016/j.asr.2005.07.027

Xiang, L., Wang, H., Steffen, H., Wu, P., Jia, L., Jiang, L., Shen, Q., 2016. Groundwater storage changes in the Tibetan Plateau and adjacent areas revealed from GRACE satellite gravity data. Earth Planet. Sci. Lett. 449, 228-239. doi:10.1016/j.epsl.2016.06.002

Yuan, Y., Zeng, G., Liang, J., Huang, L., Hua, S., Li, F., Zhu, Y., Wu, H., Liu, J., He, X., He, Y., 2015. Variation of water level in Dongting Lake over a 50-year period: Implications for the impacts of anthropogenic and climatic factors. J. Hydrol. 525, 450-456. doi:10.1016/j.jhydrol.2015.04.010

Zhang, S., Gao, H., Naz, B.S., 2014. Monitoring reservoir storage in South Asia from multisatellite remote sensing. Water Resour. Res. 50, 8927-8943. doi:10.1002/2014WR015829

Zhang, Y., Deng, H., Kung, H. Te, Li, W., Li, J., 2009. Research on the changes in lake wetland in Hubei Province. Proc. - 2009 Int. Conf. Environ. Sci. Inf. Appl. Technol. ESIAT 2009 2, 185-187. doi:10.1109/ESIAT.2009.369

Zhao, Q., Wu, W., Wu, Y., 2015. Variations in China's terrestrial water storage over the past decade using GRACE data. Geod. Geodyn. 6, 187-193. doi:10.1016/j.geog.2015.03.004 